\title{
Importance of the Rhizosphere Microbiota in Iron Biofortification of Plants
}

\section{OPEN ACCESS}

Edited by: Eduardo V. Soares, Instituto Superior de Engenharia do Porto (ISEP), Portugal

Reviewed by:

Manuel González-Guerrero, Polytechnic University of Madrid,

Spain

Kanchan Vishwakarma, Swedish University of Agricultural Sciences, Sweden

Rama Kant Dubey,

Banaras Hindu University, India

*Correspondence: Sylvie Mazurier sylvie.mazurier@inrae.fr

Specialty section: This article was submitted to Plant Abiotic Stress,

a section of the journal Frontiers in Plant Science

Received: 20 July 2021 Accepted: 29 October 2021 Published: 03 December 2021

Citation:

Lurthy T, Pivato B, Lemanceau P and Mazurier S (2021) Importance of the Rhizosphere Microbiota in Iron Biofortification of Plants.

Front. Plant Sci. 12:744445. doi: $10.3389 / \mathrm{fp} / \mathrm{s} .2021 .744445$
Tristan Lurthy, Barbara Pivato, Philippe Lemanceau and Sylvie Mazurier*

Agroécologie, AgroSup Dijon, INRAE, University of Bourgogne, University of Bourgogne Franche-Comté, Dijon, France

Increasing the iron content of plant products and iron assimilability represents a major issue for human nutrition and health. This is also a major challenge because iron is not readily available for plants in most cultivated soils despite its abundance in the Earth's crust. Iron biofortification is defined as the enhancement of the iron content in edible parts of plants. This biofortification aims to reach the objectives defined by world organizations for human nutrition and health while being environment friendly. A series of options has been proposed to enhance plant iron uptake and fight against hidden hunger, but they all show limitations. The present review addresses the potential of soil microorganisms to promote plant iron nutrition. Increasing knowledge on the plant microbiota and plant-microbe interactions related to the iron dynamics has highlighted a considerable contribution of microorganisms to plant iron uptake and homeostasis. The present overview of the state of the art sheds light on plant iron uptake and homeostasis, and on the contribution of plant-microorganism (plant-microbe and plant-plant-microbe) interactions to plant nutritition. It highlights the effects of microorganisms on the plant iron status and on the co-occurring mechanisms, and shows how this knowledge may be valued through genetic and agronomic approaches. We propose a change of paradigm based on a more holistic approach gathering plant and microbial traits mediating iron uptake. Then, we present the possible applications in plant breeding, based on plant traits mediating plant-microbe interactions involved in plant iron uptake and physiology.

Keywords: iron, biotic interactions, plant-microbe interaction, microbiota, plant nutrition, iron biofortification, rhizosphere

\section{INTRODUCTION}

More than 820 million people are suffering from chronic undernourishment, and two billion from micronutrient deficiencies (hidden hunger) worldwide (FAO et al., 2019). People from lowermiddle-income countries suffer from hunger (undernourishment) and do not have access to a varied diet (malnutrition). This is leading to micronutrient deficiencies (MNDs) in micronutrients such as iron $(\mathrm{Fe})$, Zinc $(\mathrm{Zn})$ and vitamin A. Overcoming undernourishment and overcoming malnutrition represent two of the main "Sustainable Development Goals" of the United Nations Development Program UNDP 2015 (UNDP, 2015).

Iron deficiency - the main case of MND in the world-has serious effects on human health, such as microcytic anemia, impaired immune function and poor endocrine function (Bailey et al., 2015; 
Wakeel et al., 2018; World Health Organization, 2021). Iron plays an essential role in the physiology of living organisms, e.g., in DNA synthesis, respiration, and photosynthesis (Aisen et al., 2001).

Meat is the main source of iron in food, with $20-60 \%$ of $\mathrm{Fe}$ in the form of haemoproteins that are easily assimilable by the human body (Cross et al., 2012). However, a significant fraction of the world human population does not have access to meat and thus suffers from iron deficiency. This deficiency also occurs in developed countries, especially among young ladies (Beck et al., 2014). In plant-based diets in developing countries, iron is supplied by plant products, especially grains (cereals and legumes). However, these grains contain low levels of $\mathrm{Fe}$, and even more include anti-nutritional compounds such as phytates which hamper Fe assimilation (Gómez-Galera et al., 2010). Yet, the iron concentration in grains has decreased over the years because of intensified agriculture, e.g., with the introduction of semi-dwarf, high-yielding cultivars of wheat (Fan et al., 2008). At the same time, meat consumption is decreasing in developed countries with the growing concern for environmental (higher environmental footprint of animal proteins than of plant proteins) and diet issues. Thus, increasing Fe content and assimilability in plant products represents a major challenge for human nutrition and health.

To address this challenge, food fortification, which consists in artificially supplementing food with micronutrients (iron, zinc, vitamins), has been proposed as an option. The Food Fortification Initiative ${ }^{1}$ created a network of governmental and private agencies in several developing countries to promote the iron fortification of wheat flour. As a result, the consumption of Fe-fortified wheat flour has increased from 18\% in 2004 to $27 \%$ in 2007 , allievating iron deficiency for 540 million people (White and Broadley, 2009). Promising results were also obtained in India, the Philippines and Rwanda with rice, pearl millet and beans supplemented with iron (Finkelstein et al., 2017, 2019). However, there are limitations to this approach. Costs are important, supplementation may modify food taste and is not always well accepted, and finally fortified food hardly reaches poor people with limited or no access to commercial channels. Iron fertilization is a common agricultural practice also used to mitigate plant iron deficiency but not considered so far overlooked to increase staple food quality. Three main groups of $\mathrm{Fe}$ fertilizers are used: inorganic $\mathrm{Fe}$ compounds, synthetic Fe, and organic Fe complexes (Abadía et al., 2011; Zanin et al., 2019). In addition to their high cost, the possible incorporation of these ligands into edible parts of the plant (Abadía et al., 2011) may represent a problem. These limitations also apply to new nano-chelates under development (Yuan et al., 2018). Indeed, the increasing use of nanoparticles raises concerns for human health or the environment (Soares and Soares, 2021). In short, efficient Fe fertilizers have several drawbacks: they are expensive, their efficiency is variable, and they can be incorporated in the host plant including its edible parts. They do not represent sustainable options for increasing the iron content of agricultural products, even if

${ }^{1}$ http://www.ffinetwork.org/ foliar applications of iron may be of interest in specific cases (e.g., increasing the iron content of rice and barley grains, Slamet-Loedin et al., 2015).

Another option relies on iron biofortification, the promotion of the iron content of plants, especially their edible parts such as leaves (e.g., lettuce or spinach), roots (e.g., carrot or cassava), fruits (e.g., peach or apple), and grains (e.g., rice, wheat, maize). This biofortification relies on better plant iron nutrition and on the modulation of iron homeostasis. This option was reported to be more efficient, sustainable and cheaper than micronutrient fortification (Murgia et al., 2012; World Health Organization, 2017). According to the FAO, "biofortified crop varieties are those which have been nutritionally enhanced using conventional plant breeding or modern biotechnology, especially recombinant DNA techniques. However, by far the most widely adopted biofortified crop varieties have been those developed through conventional crop breeding" (FAO, 2019, 2021). Approximately 90 iron-biofortified crop varieties have been released in different part of the world (FAO, 2019; Singh and Prasanna, 2020) and help fight hidden hunger, but much progress remains to be made. Iron biofortification represents a major challenge because $\mathrm{Fe}$ is not readily available for living organisms, including plants, in most cultivated soils despite its abundance: $\mathrm{Fe}$ is the fourth element in the Earth's crust (Lemanceau et al., 2009). Low iron availability is particularly acute in alkaline soils which represent about $30 \%$ of the world's croplands and up to $40 \%$ of arable surfaces (Chen and Barak, 1982; Sullivan and Gadd, 2019). Iron availability depends on the soil properties and more specifically on the soil $\mathrm{pH}$ and redox potential (Robin et al., 2008; Colombo et al., 2014). Immobilization of iron in the form of scarcely soluble complexes formed between $\mathrm{Fe}^{3+}$ and hydroxides, oxyhydroxides, and oxides, increases with the soil pH (Robin et al., 2008). The low availability of iron may lead to plant growth depression and even to iron deficiency chlorosis (IDC), interveinal chlorosis, which ultimately negatively impact crop yield (Briat et al., 2015) and quality (their Fe content).

Soil microorganisms have long been known to contribute to plant iron nutrition (Marschner, 1995). This beneficial effect was first showed by comparing the iron contents of plants grown in sterile and non-sterile soils. The iron content of sunflower, maize (Masalha et al., 2000), rape and red clover (Rroço et al., 2003; Jin et al., 2006) was significantly lower when they were grown in sterile rather than non-sterile soil; sunflower even suffered from chlorosis in sterile soil. A high occurrence of oligotrophic bacteria in lupine rhizosphere was associated with an increased concentration of $\mathrm{Fe}, \mathrm{Cu}, \mathrm{Mn}$ and $\mathrm{Zn}$ in plant shoots, suggesting that these bacteria may contribute to plant iron and more generally to plant mineral nutrition (De Santiago et al., 2019). The promotion of iron nutrition in a range of plant species by various microbial strains (e.g., root symbionts) and metabolites has been reported in a series of studies listed in Table 1. Interactions between plants may also facilitate their iron nutrition. Intercropping cereal and legume plants can notably improve their iron content (Zuo et al., 2000; Gunes et al., 2007; Zuo and Zhang, 2009; Xue et al., 2016). Thus, maize-peanut intecropping improved Fe nutrition of peanut 
TABLE 1 | Microorganisms and microbial metabolites mediating the plant iron status.

\begin{tabular}{|c|c|c|c|c|c|c|c|}
\hline $\begin{array}{l}\text { Microorganisms and/or } \\
\text { microbial metabolites }\end{array}$ & $\begin{array}{l}\text { Application } \\
\text { modes }\end{array}$ & Plants & $\begin{array}{l}\text { Effects on the plant } \\
\text { iron status }\end{array}$ & Additional observations & $\begin{array}{l}\text { Effects on plant } \\
\text { genes }\end{array}$ & $\begin{array}{l}\text { Mechanism(s) proposed } \\
\text { by authors }\end{array}$ & References \\
\hline $\begin{array}{l}\text { Acinetobacter calcoaceticus } \\
\text { O-13; Bacillus simplex K-10 }\end{array}$ & $\begin{array}{l}\text { Bacterial } \\
\text { suspension }\end{array}$ & Potato & Plant $[\mathrm{Fe}] / \mathrm{Fe}^{(1) \nearrow(2)}$ & $\begin{array}{l}\text { Tryptophan addition enhance } \\
\text { iron uptake }\end{array}$ & & Sid. ${ }^{(3)}$ iron mobilization & $\begin{array}{l}\text { Mushtaq et al., } \\
2021\end{array}$ \\
\hline $\begin{array}{l}\mathrm{N}_{2} \text { fixer and/or auxin producer } \\
\text { mutants of Azospirillum } \\
\text { brasilence FP2 }\end{array}$ & $\begin{array}{l}\text { Bacterial } \\
\text { suspension }\end{array}$ & Maize & $\begin{array}{l}\text { Plant }[\mathrm{Fe}] / \mathrm{Fe} \nearrow, \\
\text { modif. } \mathrm{Fe} \text { distrib } \\
(3)\end{array}$ & $\begin{array}{l}\text { Root ethylene production } \searrow^{(4)} \text {, } \\
\text { root auxin and } \mathrm{DIMBOA}^{(5)} \\
\text { production } \nearrow \text {, } \\
\text { metabolic partitioning of carbon } \\
\text { differed }\end{array}$ & & $\begin{array}{l}\text { Regulation of hormone } \\
\text { signaling and cellular iron } \\
\text { transport }\end{array}$ & $\begin{array}{l}\text { Housh et al., } \\
2021\end{array}$ \\
\hline $\begin{array}{l}\text { Gluconacetobacter } \\
\text { diazotrophicus PAL5; } \\
\text { Azospirillum brasilense REC3 }\end{array}$ & $\begin{array}{l}\text { Bacterial } \\
\text { suspension }\end{array}$ & Strawberry & Plant [Fe]/Fe $\nearrow$ & $\begin{array}{l}\text { Phenolic compounds } \\
\text { content } \searrow \text {, } \\
\text { chlorophyll } \nearrow\end{array}$ & & Sid. iron mobilization & $\begin{array}{l}\text { Delaporte- } \\
\text { Quintana et al., } \\
2020\end{array}$ \\
\hline $\begin{array}{l}\text { Pseudomonas spp.; } \\
\text { Enterobacter spp.; } \\
\text { Bacillus sporothernodurans }\end{array}$ & $\begin{array}{l}\text { Bacterial } \\
\text { suspension }\end{array}$ & Sunflower & Plant $[\mathrm{Fe}] / \mathrm{Fe} \nearrow$ & $\begin{array}{l}\text { Sid. }{ }^{(6)} \text { production } \nearrow \text {, } \\
\text { phytohormone production } \nearrow \text {, } \\
\text { phosphate solubilization } \nearrow \text {, } \\
\mathrm{HCN}^{(7)} \text { production } \nearrow\end{array}$ & & Sid. iron mobilization & $\begin{array}{l}\text { Pourbabaee } \\
\text { et al., } 2018\end{array}$ \\
\hline Burkholderia cepacia JFW16 & $\begin{array}{l}\text { Bacterial } \\
\text { suspension }\end{array}$ & Milkvetch & Plant $[\mathrm{Fe}] / \mathrm{Fe} \nearrow$ & $\begin{array}{l}\text { Rhizosphere acidification, root } \\
\mathrm{FR}^{(8)} \nearrow \text {, flavin release, sid. and } \\
\text { phytohormone production } \nearrow\end{array}$ & $\begin{array}{l}\text { FRO2 expr. }{ }^{(9)} \nearrow \\
\text { IRT1 } \text { expr. } \nearrow \\
\text { AHA2 expr. } \nearrow \\
\text { FIT1 expr. } \nearrow\end{array}$ & $\begin{array}{l}\text { Promotion of iron } \\
\text { mobilization by acidification, } \\
\text { strategy I iron uptake, and } \\
\text { hormonal regulation }\end{array}$ & $\begin{array}{l}\text { Zhou et al., } \\
2018\end{array}$ \\
\hline $\begin{array}{l}\text { Pseudomonas fluorescens } \\
\text { ATCC13525 }\end{array}$ & $\begin{array}{l}\text { Bacterial } \\
\text { suspension }\end{array}$ & Tomato & Plant $[\mathrm{Fe}] / \mathrm{Fe} \nearrow$ & & $\begin{array}{l}\text { IRT1 expr. } \nearrow, F R O 2 \\
\text { expr. } \nearrow, \text { NRAMP3 } \\
\text { expr. } \nearrow\end{array}$ & $\begin{array}{l}\text { Promotion of strategy I iron } \\
\text { uptake, and redistribution }\end{array}$ & Nagata, 2017 \\
\hline $\begin{array}{l}\text { Burkholderia terricola } \\
\text { LMG20594; Pseudomonas } \\
\text { brassicacearum NFM421; } \\
\text { B. pyrrocinia LMG14191; } \\
\text { P. mandelii NBRC103147; } \\
\text { Herbaspirillum huttiense } \\
\text { NBRC10252 }\end{array}$ & $\begin{array}{l}\text { Bacterial } \\
\text { suspension }\end{array}$ & Lentil, pea & Plant $[\mathrm{Fe}] / \mathrm{Fe} \nearrow$ & $\begin{array}{l}\text { Rhizosphere acidification, sid. } \\
\text { production } \nearrow \text {, phytohormone } \\
\text { production } \nearrow\end{array}$ & & Iron uptake & Reza, 2017 \\
\hline $\begin{array}{l}\text { Paenibacillus polymyxa } \\
\text { BFKC01 }\end{array}$ & $\begin{array}{l}\text { Bacterial } \\
\text { suspension }\end{array}$ & Arabidopsis & Plant [Fe]/Fe $\nearrow$ & Root FR $\nearrow$ & $\begin{array}{l}\text { FRO2 expr. } \nearrow \text {, IRT1 } \\
\text { expr. } \nearrow, \text { FIT1 } \\
\text { expr. } \nearrow \mathrm{MYB72} \\
\text { expr. } \nearrow\end{array}$ & $\begin{array}{l}\text { Promotion of iron uptake by } \\
\text { modulation of the } \\
\text { expression of strategy I key } \\
\text { genes and of ISR key genes }\end{array}$ & $\begin{array}{l}\text { Zhou et al., } \\
2016\end{array}$ \\
\hline $\begin{array}{l}\text { Rhizobium leguminosarum } \\
\text { bv. }{ }^{(10)} \text { phaseoli; Pseudomonas } \\
\text { spp. Avm }\end{array}$ & $\begin{array}{l}\text { Bacterial } \\
\text { suspension }\end{array}$ & $\begin{array}{l}\text { Common } \\
\text { bean }\end{array}$ & $\begin{array}{l}\text { Plant }[\mathrm{Fe}] / \mathrm{Fe} \nearrow \text {, } \\
\text { modif. Fe distrib. }\end{array}$ & $\begin{array}{l}\text { Wild variety more efficient in } \mathrm{Fe} \\
\text { uptake than cultivated variety } \\
\text { after microbial inoculation }\end{array}$ & & Promotion of iron uptake & $\begin{array}{l}\text { Carrillo- } \\
\text { Castañeda } \\
\text { et al., } 2005\end{array}$ \\
\hline $\begin{array}{l}\text { Bacillus subtilis CPA; Bacillus } \\
\text { sp. AHP3; Pseudomonas } \\
\text { chlororaphis PR29; Glomus } \\
\text { fasciculatum } \\
\text { (consortium) }\end{array}$ & $\begin{array}{l}\text { Bacterial and fungal } \\
\text { suspension }\end{array}$ & Wheat & Plant [Fe]/Fe $\nearrow$ & $\begin{array}{l}\text { Grain protein content } \nearrow \\
\text { superoxide dismutase (SOD) } \nearrow \\
\text { catalase }(\mathrm{CAT}) \searrow \text {, chlorophyll } \nearrow \\
\text { Metabolome modification }\end{array}$ & & $\begin{array}{l}\text { Promotion of nutrient yield } \\
\text { by metabolic regulation and } \\
\text { ROS scavenging activity }\end{array}$ & $\begin{array}{l}\text { Yadav et al., } \\
2020\end{array}$ \\
\hline $\begin{array}{l}\text { Arthrobacter sulfonivorans } \\
\text { DS-68; Enterococcus hirae } \\
\text { DS-163 }\end{array}$ & Bacterial coating & Wheat & $\begin{array}{l}\text { Plant }[\mathrm{Fe}] / \mathrm{Fe} \nearrow, \text {, seed } \\
{[\mathrm{Fe}] / \mathrm{Fe} \nearrow \text {, modif. } \mathrm{Fe}} \\
\text { assimil. }^{(11)}\end{array}$ & Anti-nutritional factor $\searrow$ & & Promotion of iron uptake & $\begin{array}{l}\text { Singh et al., } \\
2018\end{array}$ \\
\hline
\end{tabular}


TABLE 1 | (Continued)

\begin{tabular}{|c|c|c|c|c|c|c|c|}
\hline $\begin{array}{l}\text { Microorganisms and/or } \\
\text { microbial metabolites }\end{array}$ & $\begin{array}{l}\text { Application } \\
\text { modes }\end{array}$ & Plants & $\begin{array}{l}\text { Effects on the } \\
\text { plant iron status }\end{array}$ & Additional observations & $\begin{array}{l}\text { Effects on plant } \\
\text { genes }\end{array}$ & $\begin{array}{l}\text { Mechanism(s) proposed } \\
\text { by authors }\end{array}$ & References \\
\hline $\begin{array}{l}\text { Bacillus subtilis BHHU10, } \\
\text { Trichoderma harzianum } \\
\text { TNHU27, and Pseudomonas } \\
\text { aeruginosa PJHU15 } \\
\text { (consortium) }\end{array}$ & $\begin{array}{l}\text { Bacterial and fungal } \\
\text { coating }\end{array}$ & Pea & Modif. Fe assimil. & $\begin{array}{l}\text { Phenolics, flavonoids, ascorbic } \\
\text { acid and protein content } \nearrow\end{array}$ & & $\begin{array}{l}\text { Promotion of ROS } \\
\text { scavenging activity in plants }\end{array}$ & Jain et al., 2014 \\
\hline $\begin{array}{l}\text { Pseudomonas fluorescens } \\
\text { C7R12; pyoverdine of } \\
\text { P. fluorescens C7R12 }\end{array}$ & $\begin{array}{l}\text { Bacterial } \\
\text { suspension; } \\
\text { apo-siderophore }\end{array}$ & Arabidopsis & $\begin{array}{l}\text { Root }[\mathrm{Fe}] / \mathrm{Fe} \searrow \text {, } \\
\text { shoot }[\mathrm{Fe}] / \mathrm{Fe} \nearrow\end{array}$ & $\begin{array}{l}\text { Changes in plant hormone } \\
\text { production, Incorporation of } \\
\text { Fe-pyoverdine suggested by } \\
{ }^{15} \mathrm{~N} \text {-labeling and } \\
\text { immunodetection }\end{array}$ & $\begin{array}{l}\text { Numerous } \\
\text { modifications } \\
\text { evidenced in a } \\
\text { transcriptomic } \\
\text { study }\end{array}$ & $\begin{array}{l}\text { Sid. promotion of iron } \\
\text { mobilization in the } \\
\text { rhizosphere including the } \\
\text { apoplast, of strategy I iron } \\
\text { uptake, and regulation of } \\
\text { hormone signaling }\end{array}$ & $\begin{array}{l}\text { Trapet et al., } \\
2016\end{array}$ \\
\hline B. subtilis GBO3 & $\begin{array}{l}\text { Bacterial } \\
\text { suspension; } \\
\text { Bacterial VOCs }{ }^{(12)}\end{array}$ & Arabidopsis & Plant $[\mathrm{Fe}] / \mathrm{Fe} \nearrow$ & $\begin{array}{l}\text { Rhizosphere acidification, root } \\
\text { FR } \nearrow\end{array}$ & $\begin{array}{l}\text { FRO2 expr. } \nearrow, I R T 1 \\
\text { expr. } \nearrow, \\
\text { FIT1 expr. } \nearrow\end{array}$ & $\begin{array}{l}\text { Promotion of iron } \\
\text { mobilization by acidification } \\
\text { and of strategy I iron uptake }\end{array}$ & $\begin{array}{l}\text { Zhang et al., } \\
2009\end{array}$ \\
\hline $\begin{array}{l}\text { Bacillus amyloliquefaciens } \\
\text { BF06 }\end{array}$ & Bacterial VOCs & Arabidopsis & Plant $[\mathrm{Fe}] / \mathrm{Fe} \nearrow$ & $\begin{array}{l}\text { Root FR } \nearrow \text {, } \\
\mathrm{Fe}^{2+} \text { production } \nearrow \text {, Production } \\
\text { of VOCs implied ( } 2 \mathrm{R} \text { or } \\
\text { 3R-butanediol) }\end{array}$ & $\begin{array}{l}\text { FRO2 expr. } \nearrow, I R T 1 \\
\text { expr. } \nearrow, F I T 1 \\
\text { expr. } \nearrow\end{array}$ & $\begin{array}{l}\text { Promotion of strategy I iron } \\
\text { uptake through gene } \\
\text { expression modulation }\end{array}$ & $\begin{array}{l}\text { Wang et al., } \\
2017\end{array}$ \\
\hline $\begin{array}{l}\text { Arthrobacter sulfonivorans } \\
\text { DS-68; Arthrobacter sp. } \\
\text { DS-179 }\end{array}$ & $\begin{array}{l}\text { Liquid bacterial } \\
\text { culture coating }\end{array}$ & Wheat & Plant $[\mathrm{Fe}] / \mathrm{Fe} \nearrow$ & Organic acid production $\nearrow$ & ZIP expr. $\nearrow$ & $\begin{array}{l}\text { Promotion of iron uptake } \\
\text { and translocation through } \\
\text { organic acid production } \\
\text { and stimulation of iron } \\
\text { transporters }\end{array}$ & $\begin{array}{l}\text { Singh et al., } \\
2017\end{array}$ \\
\hline B. subtilis $\mathrm{GBO} 3$ & $\begin{array}{l}\text { Liquid bacterial } \\
\text { culture }\end{array}$ & Cassava & Shoot $[\mathrm{Fe}] / \mathrm{Fe} \nearrow$ & & & $\begin{array}{l}\text { Promotion of the plant iron } \\
\text { status through the } \\
\text { regulation of the plant iron } \\
\text { metabolism including } \\
\text { hormone signaling }\end{array}$ & $\begin{array}{l}\text { Freitas et al., } \\
2015\end{array}$ \\
\hline $\begin{array}{l}\text { Paenibacillus cookie JGR8; } \\
\text { Pseudomonas } \\
\text { pseudoalcaligenes JGR2; } \\
\text { Bacillus megaterium JGR9 }\end{array}$ & $\begin{array}{l}\text { Liquid bacterial } \\
\text { culture }\end{array}$ & $\begin{array}{l}\text { Lesser } \\
\text { bullrush }\end{array}$ & $\begin{array}{l}\text { Shoot }[\mathrm{Fe}] / \mathrm{Fe} \nearrow \text { for } \\
\text { strain JGR2, modif. } \\
\text { Fe distrib. }\end{array}$ & $\begin{array}{l}\text { Sid. production } \nearrow \text {, } \\
\text { phytohormone production } \nearrow \text {, } \\
\text { phosphate solubilization } \nearrow\end{array}$ & & $\begin{array}{l}\text { Sid. promotion of iron } \\
\text { accumulation and } \\
\text { translocation; relationship } \\
\text { between sid. production } \\
\text { and phosphate } \\
\text { solubilization }\end{array}$ & $\begin{array}{l}\text { Ghosh et al., } \\
2014\end{array}$ \\
\hline Chryseobacterium spp. C138 & $\begin{array}{l}\text { Liquid bacterial } \\
\text { culture }\end{array}$ & Tomato & Plant $[\mathrm{Fe}] / \mathrm{Fe} \nearrow$ & & & $\begin{array}{l}\text { Fe-sid. used as a source of } \\
\text { iron under iron deficiency }\end{array}$ & $\begin{array}{l}\text { Radzki et al., } \\
2013\end{array}$ \\
\hline $\begin{array}{l}\text { P. putida MTCC 103, } \\
\text { Enterobacteria }\end{array}$ & $\begin{array}{l}\text { Liquid bacterial } \\
\text { culture }\end{array}$ & Rice & $\begin{array}{l}\text { Plant }[\mathrm{Fe}] / \mathrm{Fe} \nearrow \\
\text { seed }[\mathrm{Fe}] / \mathrm{Fe} \nearrow\end{array}$ & Variation of peroxidase activity & & $\begin{array}{l}\text { Promotion of iron } \\
\text { solubilization, uptake and } \\
\text { translocation related to sid. } \\
\text { production }\end{array}$ & $\begin{array}{l}\text { Sharma et al., } \\
2013\end{array}$ \\
\hline $\begin{array}{l}\text { R. leguminosarum PR1; } \\
\text { Pseudomonas sp. PGERs17 }\end{array}$ & $\begin{array}{l}\text { Liquid bacterial } \\
\text { culture }\end{array}$ & Lentil & Plant $[\mathrm{Fe}] / \mathrm{Fe} \nearrow$ & $\begin{array}{l}\text { Nodulation } \nearrow \\
\text { leghaemoglobin } \nearrow\end{array}$ & & $\begin{array}{l}\text { Fe-sid. used as a source of } \\
\text { iron under iron deficiency }\end{array}$ & $\begin{array}{l}\text { Mishra et al., } \\
2011\end{array}$ \\
\hline Trichoderma asperellum Т34 & Fungal conidia & Cucumber & Shoot $[\mathrm{Fe}] / \mathrm{Fe} \nearrow$ & & & $\begin{array}{l}\text { Fe-sid. used as a source of } \\
\text { iron under iron deficiency }\end{array}$ & $\begin{array}{l}\text { De Santiago } \\
\text { et al., } 2013\end{array}$ \\
\hline
\end{tabular}


TABLE 1 | (Continued)

\begin{tabular}{|c|c|c|c|c|c|c|c|}
\hline $\begin{array}{l}\text { Microorganisms and/or } \\
\text { microbial metabolites }\end{array}$ & $\begin{array}{l}\text { Application } \\
\text { modes }\end{array}$ & Plants & $\begin{array}{l}\text { Effects on the } \\
\text { plant iron status }\end{array}$ & Additional observations & $\begin{array}{l}\text { Effects on plant } \\
\text { genes }\end{array}$ & $\begin{array}{l}\text { Mechanism(s) proposed } \\
\text { by authors }\end{array}$ & References \\
\hline T. asperellum T34 & Fungal conidia & White lupin & Shoot $[\mathrm{Fe}] / \mathrm{Fe} \nearrow$ & $\begin{array}{l}\text { Peroxidase activity } \nearrow \text {, catalase } \\
\text { activity } \nearrow\end{array}$ & & $\begin{array}{l}\text { Sid. promotion of iron } \\
\text { accumulation and } \\
\text { translocation under iron } \\
\text { deficiency; promotion of } \\
\text { ROS scavenging activity is } \\
\text { implied }\end{array}$ & $\begin{array}{l}\text { De Santiago } \\
\text { et al., } 2009\end{array}$ \\
\hline Hymenoscyphus ericae & Fungal suspension & Heather & Plant $[\mathrm{Fe}] / \mathrm{Fe} \nearrow$ & $\begin{array}{l}\text { Variation in results depending } \\
\text { on calcium addition }\end{array}$ & & Sid. iron mobilization & $\begin{array}{l}\text { Leake et al., } \\
1990\end{array}$ \\
\hline $\begin{array}{l}\text { Glomus etunicatum WV579A, G. } \\
\text { diaphanum WV579B, } \\
\text { G. intraradices WV894 }\end{array}$ & Fungal cultures & Maize & Root [Fe]/Fe $\nearrow$ & $\begin{array}{l}\text { Variation in results depending } \\
\text { on soil pH and fungal strain }\end{array}$ & & Sid. iron mobilization & $\begin{array}{l}\text { Clark and Zeto, } \\
1996\end{array}$ \\
\hline $\begin{array}{l}\text { Glomus mossae and rhizosphere } \\
\text { microorganisms }\end{array}$ & $\begin{array}{l}\text { Fungal spores, root } \\
\text { pieces and soil }\end{array}$ & $\begin{array}{l}\text { Peanut, } \\
\text { sorghum }\end{array}$ & $\begin{array}{l}\text { Plant }[\mathrm{Fe}] / \mathrm{Fe} \nearrow \\
\text { modif. Fe distrib. }\end{array}$ & Plant phosphate $\nearrow$ & & Increased soil exploration & $\begin{array}{l}\text { Caris et al., } \\
1998\end{array}$ \\
\hline $\begin{array}{l}\text { Glomus mossae, G. albidum, G. } \\
\text { fasciculatum, G. macrocarpum. }\end{array}$ & $\begin{array}{l}\text { Fungal spores } \\
\text { propagated in } \\
\text { sterile soil }\end{array}$ & $\begin{array}{l}\text { Galleta } \\
\text { grass }\end{array}$ & Plant $[\mathrm{Fe}] / \mathrm{Fe} \nearrow$ & use of ${ }^{59} \mathrm{Fe}$ & & $\begin{array}{l}\text { Sid. iron mobilization and } \\
\text { transport into mycorrhizal } \\
\text { plants }\end{array}$ & $\begin{array}{l}\text { Cress et al., } \\
1986\end{array}$ \\
\hline Glomus intraradices & $\begin{array}{l}\text { Commercial } \\
\text { inoculant }\end{array}$ & Maize & $\begin{array}{l}\text { Shoot }[\mathrm{Fe}] / \mathrm{Fe} \nearrow \\
\text { Shoot }[\mathrm{Fe}] / \mathrm{Fe} \searrow\end{array}$ & $\begin{array}{l}\text { Variation in results with amount } \\
\text { of micronutrients and } \mathrm{P} \text { added }\end{array}$ & & Increased soil exploration & Liu et al., 2000 \\
\hline $\begin{array}{l}\text { Arbuscular mycorrhiza fungi } \\
\text { inoculant }\end{array}$ & $\begin{array}{l}\text { Commercial } \\
\text { inoculant }\end{array}$ & Chickpea & Plant $[\mathrm{Fe}] / \mathrm{Fe} \nearrow$ & $\begin{array}{l}\text { No effect of mineral } N \\
\text { fertilization }\end{array}$ & & Increased soil exploration & $\begin{array}{l}\text { Farzaneh et al., } \\
2011\end{array}$ \\
\hline $\begin{array}{l}\text { Glomus intraradices, G. mosseae, } \\
\text { G. aggregatum, } \\
\text { G. etunicatum }\end{array}$ & $\begin{array}{l}\text { Commercial } \\
\text { inoculant }\end{array}$ & Sorghum & Plant [Fe]/Fe $\nearrow$ & $\begin{array}{l}\text { Plant biomass } \nearrow \text {, } \\
\text { chlorophyll } \nearrow \text {, } \\
\text { Plant } \mathrm{S} \nearrow \text {, } \\
\text { ROS } \searrow\end{array}$ & $\begin{array}{l}\text { DMAS2 exp. } \nearrow \\
\text { NAS2 exp. } \nearrow \\
\text { YS1 exp., } \nearrow\end{array}$ & $\begin{array}{l}\text { Promotion of strategy II iron } \\
\text { uptake (PS } \nearrow \text { ), and of ROS } \\
\text { scavenging activity }\end{array}$ & $\begin{array}{l}\text { Prity et al., } \\
2020\end{array}$ \\
\hline $\begin{array}{l}\text { Glomus intraradices, G. mosseae, } \\
\text { G. aggregatum, } \\
\text { G. etunicatum }\end{array}$ & Fungal spores (mix) & Alfalfa & Plant [Fe]/Fe $\nearrow$ & $\begin{array}{l}\text { Plant biomass } \nearrow \text {, } \\
\text { chlorophyll } \nearrow \\
\text { plant } \mathrm{S} \nearrow \\
\text { root } \mathrm{FR} \nearrow \\
\mathrm{ROS} \searrow\end{array}$ & $\begin{array}{l}\text { FRO expr. } \nearrow, \\
\text { SULTR }(1 ; 1, \\
1 ; 2,1 ; 3,3 ; 1) \\
\text { expr. } \nearrow\end{array}$ & $\begin{array}{l}\text { Promotion of iron } \\
\text { mobilization in the } \\
\text { rhizosphere including the } \\
\text { root apoplast, and of ROS } \\
\text { scavenging activity }\end{array}$ & $\begin{array}{l}\text { Rahman et al., } \\
2020\end{array}$ \\
\hline $\begin{array}{l}\text { Glomus intraradices, G. mosseae, } \\
\text { G. aggregatum, G. etunicatum }\end{array}$ & Fungal spores (mix) & Sunflower & Plant [Fe]/Fe $\nearrow$ & $\begin{array}{l}\text { Plant biomass } \nearrow, \\
\text { chlorophyll } \nearrow, \\
\text { root } \mathrm{FR} \nearrow \\
\operatorname{ROS} \searrow, \text { CAT } \nearrow, \\
\operatorname{SOD} \nearrow\end{array}$ & $\begin{array}{l}\text { FRO1 expr. } \nearrow, \\
\text { IRT1 expr. } \nearrow \\
\text { ZIP1 expr. } \nearrow\end{array}$ & $\begin{array}{l}\text { Promotion of iron } \\
\text { mobilization and uptake, } \\
\text { and ROS scavenging } \\
\text { activity }\end{array}$ & $\begin{array}{l}\text { Kabir et al., } \\
2020\end{array}$ \\
\hline $\begin{array}{l}\text { Rhizophagus irregularis } \\
\text { DAOM197198 }\end{array}$ & Fungal spores & Maize & Shoot $[\mathrm{Fe}] / \mathrm{Fe} \nearrow$ & $\begin{array}{l}\text { Genes implied in strategy ॥ } \\
\text { were not induced }\end{array}$ & 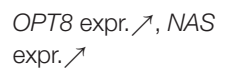 & $\begin{array}{l}\text { Selective induction of } \\
\text { putative iron transporters }\end{array}$ & $\begin{array}{l}\text { Kobae et al., } \\
2014\end{array}$ \\
\hline $\begin{array}{l}\text { Rhizophagus irregularis } \\
\text { DAOM197198 }\end{array}$ & Fungal spores & Chicory & Root $[\mathrm{Fe}] / \mathrm{Fe} \nearrow$ & $\begin{array}{l}\text { Root exploration volume } \nearrow \text {, } \\
\text { phosphatase production } \nearrow\end{array}$ & & $\begin{array}{l}\text { Increased soil exploration, } \\
\text { phosphatase activities } \\
\text { implied }\end{array}$ & $\begin{array}{l}\text { Labidi et al., } \\
2012\end{array}$ \\
\hline $\begin{array}{l}\text { Desferrioxamine B, sid. of } \\
\text { Streptomyces obtained } \\
\text { commercially }\end{array}$ & Fe-siderophore & Wheat & $\begin{array}{l}\text { Plant }[\mathrm{Fe}] / \mathrm{Fe} \searrow \text {, } \\
\text { modif. } \mathrm{Fe} \text { distrib. }\end{array}$ & $\begin{array}{l}\text { Variation of phytosiderophore } \\
\text { production }\end{array}$ & & $\begin{array}{l}\text { Sid. inhibition of iron uptake } \\
\text { via PS chelation }\end{array}$ & $\begin{array}{l}\text { Sadrarhami } \\
\text { et al., } 2021\end{array}$ \\
\hline
\end{tabular}


TABLE 1 | (Continued)

\begin{tabular}{|c|c|c|c|c|c|c|c|}
\hline $\begin{array}{l}\text { Microorganisms and/or } \\
\text { microbial metabolites }\end{array}$ & $\begin{array}{l}\text { Application } \\
\text { modes }\end{array}$ & Plants & $\begin{array}{l}\text { Effects on the } \\
\text { plant iron status }\end{array}$ & Additional observations & $\begin{array}{l}\text { Effects on plant } \\
\text { genes }\end{array}$ & $\begin{array}{l}\text { Mechanism(s) proposed } \\
\text { by authors }\end{array}$ & References \\
\hline $\begin{array}{l}3 \text { pyoverdines, sids of } \\
\text { P. fluorescens C7R12; } \\
\text { Pseudomonas sp. B4214; } \\
\text { Pseudomonas sp. D426 }\end{array}$ & Fe-siderophore & Pea & $\begin{array}{l}\text { Plant }[\mathrm{Fe}] / \mathrm{Fe} \nearrow \\
\text { modif. } \mathrm{Fe} \text { distrib. }\end{array}$ & $\begin{array}{l}\text { Effects on the plant Fe status } \\
\text { varying with pea } \mathrm{cv}^{(13)} \text { and } \\
\text { sids, modifications of the plant } \\
\text { ionome }\end{array}$ & & $\begin{array}{l}\text { Fe-sid. used as a source of } \\
\text { iron under iron deficiency }\end{array}$ & $\begin{array}{l}\text { Lurthy et al., } \\
2020\end{array}$ \\
\hline $\begin{array}{l}\text { Azotochelin, sid. of Azotobacter } \\
\text { vinelandii obtained } \\
\text { commercially }\end{array}$ & Fe-siderophore & Soybean & Plant $[\mathrm{Fe}] / \mathrm{Fe} \nearrow$ & & & Sid. iron mobilization & $\begin{array}{l}\text { Ferreira et al., } \\
2019\end{array}$ \\
\hline $\begin{array}{l}\text { Pyoverdine, sid. of } \\
\text { P. fluorescens ATCC } 13525\end{array}$ & Fe-siderophore & Tomato & Plant $[\mathrm{Fe}] / \mathrm{Fe} \nearrow$, & chlorophyll $\nearrow$ & $\begin{array}{l}\text { FRO2 expr. } \nearrow, I R T 1 \\
\text { expr. } \nearrow\end{array}$ & $\begin{array}{l}\text { Fe-sid. used as a source of } \\
\text { iron under iron deficiency }\end{array}$ & $\begin{array}{l}\text { Nagata et al., } \\
2013\end{array}$ \\
\hline $\begin{array}{l}\text { Pyoverdine, sid. of } \\
\text { P. fluorescens C7R12 }\end{array}$ & Fe-siderophore & $\begin{array}{l}\text { Arabidopsis, } \\
\text { tobacco, } \\
\text { barley, wheat, } \\
\text { fescue, rye } \\
\text { grass }\end{array}$ & Plant $[\mathrm{Fe}] / \mathrm{Fe} \nearrow$ & $\begin{array}{l}\text { Incorporation of Fe-pyoverdine } \\
\text { suggested by }{ }^{15} \mathrm{~N} \text {-labeling }\end{array}$ & & $\begin{array}{l}\text { Fe-sid. used as a source of } \\
\text { iron under iron deficiency }\end{array}$ & $\begin{array}{l}\text { Shirley et al., } \\
2011\end{array}$ \\
\hline Pseudomonas spp. sid. & Fe-siderophore & Red clover & Plant [Fe]/Fe $\nearrow$ & chlorophyll $\nearrow$ & & $\begin{array}{l}\text { Sid. iron mobilization, } \\
\text { Fe-sid. used as a source of } \\
\text { iron under iron deficiency }\end{array}$ & Jin et al., 2010 \\
\hline $\begin{array}{l}\text { Pyoverdine, sid. of } \\
\text { P. fluorescens C7R12 }\end{array}$ & Fe-siderophore & Arabidopsis & Plant $[\mathrm{Fe}] / \mathrm{Fe} \nearrow$ & $\begin{array}{l}\text { An IRT1 mutant still } \\
\text { incorporated Fe-pyoverdine, } \\
\text { incorporation of Fe-pvd } \\
\text { suggested by }{ }^{15} \mathrm{~N} \text {-labeling and } \\
\text { immunodetection }\end{array}$ & & $\begin{array}{l}\text { Fe-sid. used as a source of } \\
\text { iron under iron deficiency } \\
\text { using a non-reductive } \\
\text { uptake mechanism }\end{array}$ & $\begin{array}{l}\text { Vansuyt et al., } \\
2007\end{array}$ \\
\hline $\begin{array}{l}\text { Aerobactin, sid. of Citrobacter } \\
\text { diversus }\end{array}$ & Fe-siderophore & Soybean & Plant $[\mathrm{Fe}] / \mathrm{Fe} \nearrow$ & $\mathrm{Fe}^{2+}$ production $\searrow$ & & $\begin{array}{l}\text { Fe-sid. used as a source of } \\
\text { iron under iron deficiency } \\
\text { using a non-reductive } \\
\text { uptake mechanism }\end{array}$ & $\begin{array}{l}\text { Chen et al., } \\
2000\end{array}$ \\
\hline $\begin{array}{l}\text { Hydroxamate, sid. mixture from } \\
\text { Penicillium chrysogenum }\end{array}$ & Fe-siderophore & $\begin{array}{l}\text { Cucumber, } \\
\text { maize }\end{array}$ & Plant $[\mathrm{Fe}] / \mathrm{Fe} \nearrow$ & $\mathrm{Fe}^{2+}$ production $\nearrow$ & & Sid. iron mobilization & $\begin{array}{l}\text { Hördt et al., } \\
2000\end{array}$ \\
\hline $\begin{array}{l}\text { Rhizoferrin, sid. of Rhizopus } \\
\text { arrhizus }\end{array}$ & Fe-siderophore & Tomato & $\begin{array}{l}\text { Modif. Fe distrib., } \\
\text { root }[\mathrm{Fe}] / \mathrm{Fe} \nearrow\end{array}$ & chlorophyll $\nearrow$ & & Sid. iron mobilization & $\begin{array}{l}\text { Yehuda et al., } \\
2000\end{array}$ \\
\hline $\begin{array}{l}\text { Ferrioxamine B, sid. of } \\
\text { Streptomyces spp. obtained } \\
\text { commercially }\end{array}$ & Fe-siderophore & Onion & $\operatorname{Root}[\mathrm{Fe}] / \mathrm{Fe} \nearrow$ & Root FR unchanged & & Sid. iron mobilization & $\begin{array}{l}\text { Manthey et al., } \\
1996\end{array}$ \\
\hline $\begin{array}{l}\text { Rhizoferrin, sid. of Rhizopus } \\
\text { arrhizus }\end{array}$ & Fe-siderophore & Tomato & $\begin{array}{l}\text { Modif. Fe distrib., } \\
\text { root }[\mathrm{Fe}] / \mathrm{Fe} \nearrow\end{array}$ & & & $\begin{array}{l}\text { Fe-sid. used as a source of } \\
\text { iron under iron deficiency }\end{array}$ & $\begin{array}{l}\text { Shenker et al., } \\
1995\end{array}$ \\
\hline $\begin{array}{l}\text { Pseudobactin, syn. }{ }^{(14)} \\
\text { pyoverdine, sid. of } \\
\text { Pseudomonas putida WCS358 }\end{array}$ & Fe-siderophore & Barley & $\begin{array}{l}\text { Modif. Fe distrib., } \\
\text { root }[\mathrm{Fe}] / \mathrm{Fe} \nearrow\end{array}$ & $\begin{array}{l}\text { No Fe exchange between } \\
\text { pyoverdine and } \\
\text { phytosiderophore }\end{array}$ & & $\begin{array}{l}\text { Fe-sid. used as a source of } \\
\text { iron under iron deficiency }\end{array}$ & $\begin{array}{l}\text { Duijff et al., } \\
1994\end{array}$ \\
\hline $\begin{array}{l}\text { Ferrioxamine B, sid. of } \\
\text { Streptomyces spp. obtained } \\
\text { commercially }\end{array}$ & Fe-siderophore & Cucumber & Plant $[\mathrm{Fe}] / \mathrm{Fe} \nearrow$ & Siderophore in the xylem & & $\begin{array}{l}\text { Fe-sid. used as a source of } \\
\text { iron, uptake through the } \\
\text { transpiration stream and } \\
\text { translocation }\end{array}$ & $\begin{array}{l}\text { Wang et al., } \\
1993\end{array}$ \\
\hline
\end{tabular}




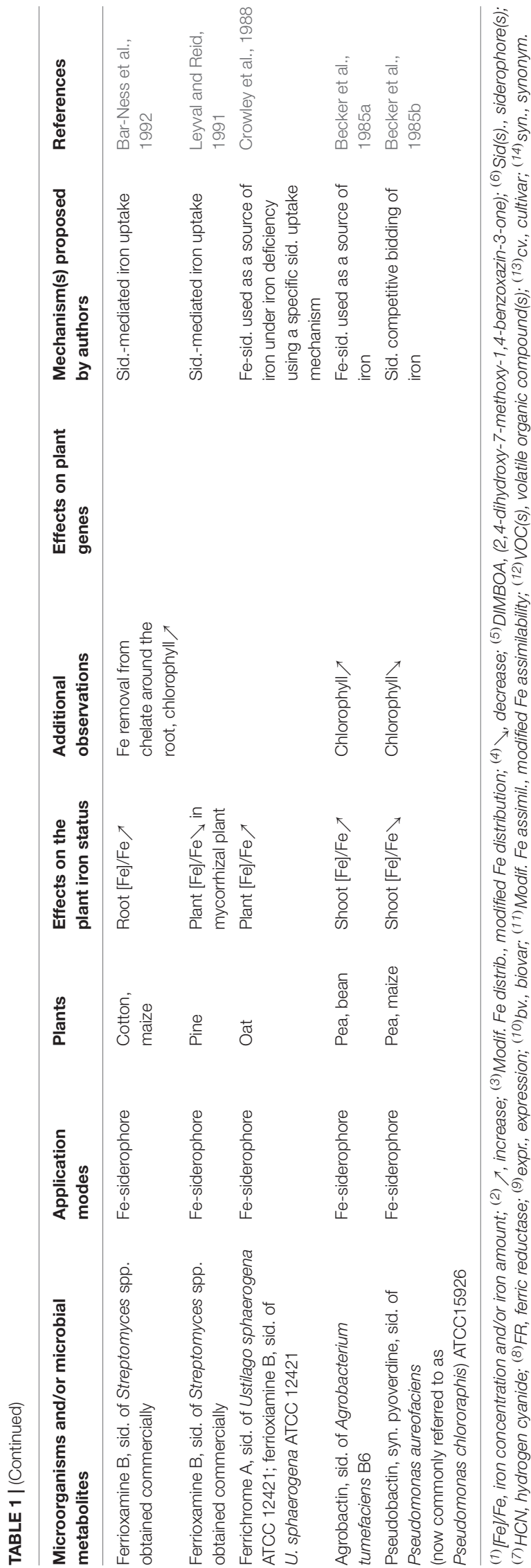

(Zuo et al., 2000), while wheat-chickpea intecropping increased the Fe concentration in wheat seeds (Gunes et al., 2007). Interestingly, the rhizosphere microbiota of these associated plant species differed from the rhizosphere microbiota of these same plants cultivated separately (Sun et al., 2009; Zhang et al., 2012; Wahbi et al., 2016a; Taschen et al., 2017). A more complex rhizosphere bacterial network was recently shown in pea-wheat intecropping (Pivato et al., 2021). Thus, we can hypothesize that the rhizosphere microbiota accounts for the increased iron uptake by intercropped plants.

On the basis of a range of studies published lately, we argue that iron biofortification is a relevant option to alleviate MND. This option requires better knowledge of the organisms and mechanisms that promote plant iron uptake and homeostasis. The present overview of the state of the art sheds light on plant iron uptake and homeostasis, and on the plantmicroorganisms interactions (plant-microbe and plant-plantmicrobe) that impact these processes. Then, we describe different strategies of iron fortification of plants, with a special focus on biofortication, and we finally discuss promising prospects based on the monitoring of the dynamic interplay between plants and their rhizosphere microbiota, including microbes from the surrounding soil, attached to and influenced by the roots, plus from the roots themselves (endophytes).

\section{BIOLOGICAL LEVERS TO PROMOTE PLANT IRON UPTAKE AND REGULATE IRON HOMEOSTASIS}

\section{Valuing Plant Genetic Resources to Improve Iron Nutrition \\ Plant Iron Physiology}

The forms of iron available to plants are the ferric iron cation $\left(\mathrm{Fe}^{3+}\right)$, or ferric-ion chelates $\left(\mathrm{Fe}^{3+}\right.$-chelates), and the ferrous iron cation $\left(\mathrm{Fe}^{2+}\right)$ (Figure 1). Two main strategies of root iron acquisition are described: strategy I (the reduction-based strategy), and strategy II (the chelation strategy) (Curie and Briat, 2003; Curie et al., 2009; Kobayashi and Nishizawa, 2012; Connorton et al., 2017). Strategy I is found in non-graminaceous monocots and dicots. It relies on the reduction of $\mathrm{Fe}^{3+}$ by a ferric reduction oxidase (encoded by a FRO gene), and the incorporation of the resulting $\mathrm{Fe}^{2+}$ into the root by an ironregulated transporter (encoded by an IRT or a RIT gene). The $\mathrm{pH}$ is decreased in the rhizosphere (Hinsinger et al., 2003), as a result of proton extrusion by plasma membrane proton pumps (encoded by an $A H A$ gene); this acidification increases $\mathrm{Fe}^{3+}$ solubility.

Strategy II is found in grasses. It relies on the excretion of phytosiderophores (PSs, structural derivatives of mugineic acid) by a transporter of mucigenic acid (encoded by a TOM gene) that chelates $\mathrm{Fe}^{3+}\left(\mathrm{Fe}^{3+}\right.$-PS) before incorporation into the root by an oligopeptide transporter belonging to the Yellow Stripe/Yellow Stripe Like family (YS/YSL) (Curie et al., 2009).

Differentiating plant species according to their iron uptake strategy has its own limitations, as both strategies are found in 


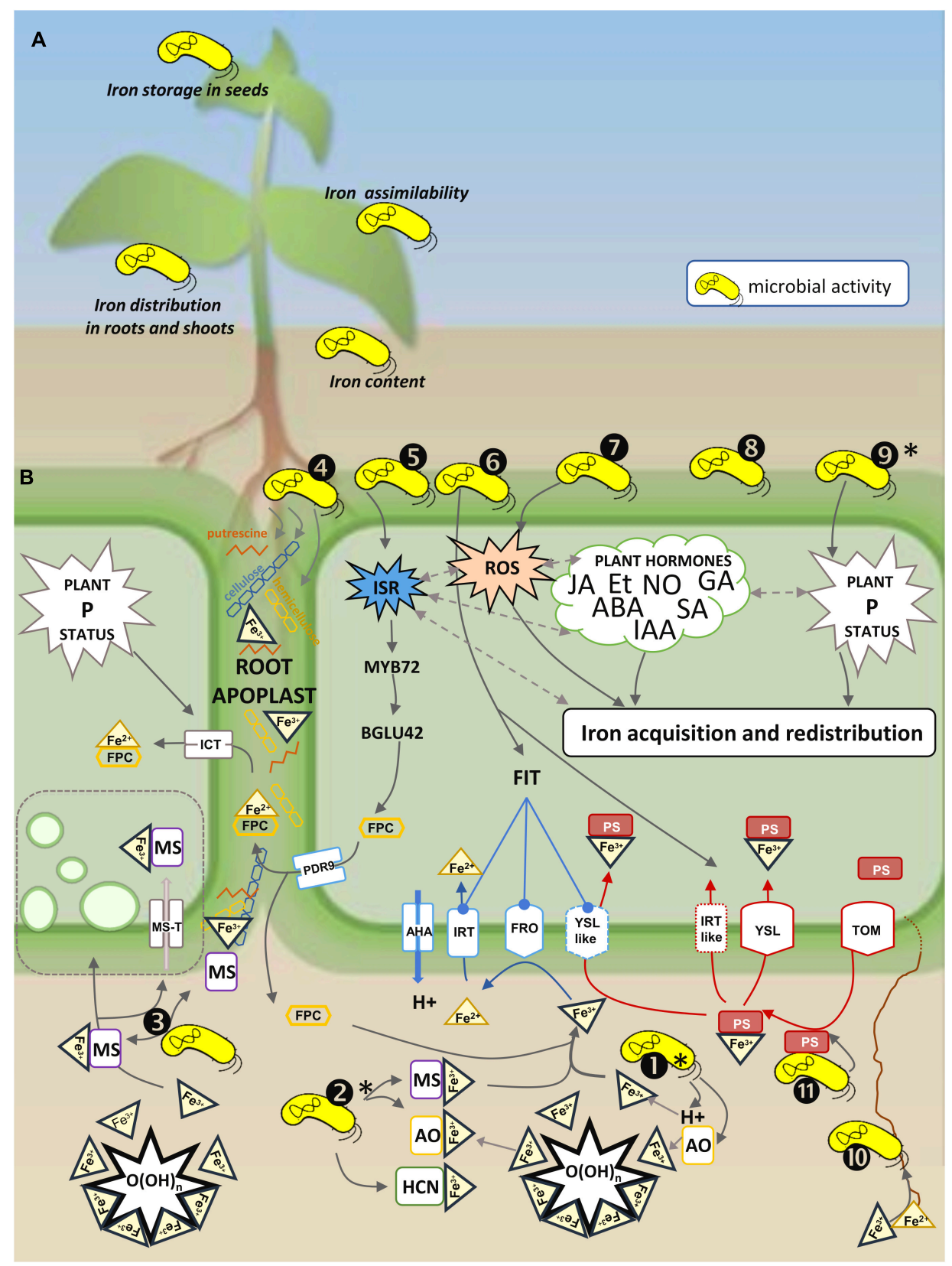

FIGURE 1 | Schematic representation of different aspects of microbial regulation of the plant iron status. (A) Types of effects of microorganisms on the plant iron status: (i) content, (ii) root and/or shoot distribution, (iii) assimilability, and (iv) iron storage in the seeds (see Table $\mathbf{1}$ for further information). (B) Microbial activities involved in the active strategy of plant iron uptake and homeostasis. Plant transporters and enzymes mediating iron uptake are represented in blue for dicots and non-graminaceous monocots, and in red for grasses. In iron uptake strategy I (reductive strategy), protons are extruded by H+-ATPases (e.g., AHA in Arabidopsis), $\mathrm{Fe}^{3+}$ is reduced by plant ferric reductases (e.g., FRO2 in Arabidopsis) to $\mathrm{Fe}^{2+}$ which is internalized in root cells by a specific transporter (e.g., IRT1 in Arabidopsis or IRT-like in rice and barley). Excretion of root fluorescent phenolic compounds (FPC) via ABC transporters (e.g., PDR9 in Arabidopsis) contributes to strategy I iron uptake and more specifically to re-mobilization of root apoplastic iron which is internalized via IRT1. In iron uptake strategy II (chelating strategy), Fe ${ }^{3+}$ is chelated by phytosiderophores (PS) (e.g., secreted via TOM1 in rice) and the Fe-PS complex is internalized by a specific transporter (e.g., YSL in rice or YSL-like in peanut). A non-reductive mechanism controlled by the plant phosphorus $(\mathrm{P})$ status implies a putative specific iron chelate transporter (ICT) possibly involved in the internalization of chelates formed by $\mathrm{Fe}^{3+}$ reduced and complexed by FPC ( $\left.\mathrm{Fe}^{2+}-\mathrm{FPC}\right)$. Numbers represent the types of microbial activities: $\mathbf{0}$ Acidification through production of protons $\left(\mathrm{H}^{+}\right)$, organic acids $(\mathrm{OA})$ and hydrogen cyanide $(\mathrm{HCN})$, and 2 Chelation by OA, $\mathrm{HCN}$ or microbial siderophores (MS) contributes to solubilization of ferric iron $\left(\mathrm{Fe}^{3+}\right)$ immobilized in $\mathrm{O}(\mathrm{OH})$ n. Acidification and chelation increase bioavailability of $\mathrm{Fe}^{3+}$ to plants. $\mathbf{B} \mathrm{Fe}^{3+}-\mathrm{MS}$ complexes are suspected to be internalized by a non-reductive process (MS transport, MS-T) with possible endocytosis (represented by green vesicles). $\mathbf{4}$ Rhizosphere microorganisms can metabolize cellulose, hemicellulose and putrescine, or produce putrescine, and thus modify molecules involved in root apoplastic iron storage and re-mobilization. GMicroorganisms triggering induced systemic plant resistance (ISR) influence FPC production; FPCs contribute to plant iron uptake by re-mobilizing root apoplastic 
FIGURE 1 | iron through the modulation of MYB72 (root transcription factor) and BGLU42 (beta-glucosidase) expression. 6Microorganisms influence the expression of key genes of plant iron uptake strategies I and II. $\boldsymbol{O M M i c r o o r g a n i s m s ~ i n f l u e n c e ~ t h e ~ p l a n t ~ r e a c t i v e ~ o x y g e n ~ s p e c i e s ~ ( R O S ) ~ s t a t u s , ~ a n d ~ t h i s ~ m o d u l a t e s ~ t h e ~ p l a n t ~ i r o n ~}$ status. 8Microorganisms influence the plant hormone (JA, jasmonic acid; Et, ethylene; ABA, abscisic acid; NO, nitric oxide; GA, gibberellin; SA, salicylic acid; IAA, indole acetic acid) status (directly by synthesizing or metabolizing them, or indirectly by inducing plant defense responses), and this modulates the plant iron status. 9Microorganisms influence the plant P status, which is implied in the regulation of the plant iron status. (1)Fungal root symbionts extend the volume of soil explored, and this improves acquisition of nutrients including iron. 11Phytosiderophore scavenging by soil bacteria influences strategy II plant iron uptake. Slash-dotted arrows indicate interrelations between various components of plant physiology influencing plant iron acquisition and redistribution. $\left({ }^{*}\right)$ influence on plant $\mathrm{P}$ bioavailability.

rice, barley and peanut (Ishimaru et al., 2006; Pedas et al., 2008; Xiong et al., 2013). In Arabidopsis (a strategy I plant), chelating agents (e.g., coumarins) may contribute to iron nutrition in addition to the reduction strategy, especially in alkaline environments (Fourcroy et al., 2014; Schmid et al., 2014; Schmidt et al., 2014). These fluorescent phenolic compounds (FPCs) are synthesized via the phenylpropanoid pathway and secreted via an ABC transporter (e.g., PDR9 in Arabidopsis). Chlorotic phenotypes of IRT1 and FRO2 mutants were not restored by FPCs from plant exudates, suggesting that strategy I is implied in the uptake of $\mathrm{Fe}^{3+}$ chelated to PC (Fourcroy et al., 2016). However, based on a review of results obtained under phosphate(Pi-) deficient conditions, Tsai and Schmidt (2017) hypothesized the existence of an auxiliary IRT1-independent iron chelate transporter (ICT) that would bypass the IRT1 uptake system and internalize the Fe-FPC complex under Pi-deficient conditions. Flavins, another family of phenolic compounds, also increased iron solubilization in the rhizosphere of other plant species (e.g., barrel medic, sugar beet) than Arabidopsis (Rodríguez-Celma et al., 2013; Sisó-Terraza et al., 2016). Iron solubilization by phenolic compounds has also been reported in rice, a strategy II plant (Bashir et al., 2010; Ishimaru et al., 2011). Besides PSs and FPCs, organic acids (e.g., citrate or succinate) chelate $\mathrm{Fe}^{3+}\left(\mathrm{Fe}^{3+}\right.$ OC) and contribute to plant iron nutrition (Abadía et al., 2011; Adeleke et al., 2017). Synthetic ferric chelates (Fe $\left.{ }^{3+}-\mathrm{SC}\right)$-e.g., Fe-EDDHA or Fe-EDTA -, may provide iron to strategy I plants; entire chelates have been found in roots and shoots (Orera et al., 2009, 2010). These small hydrophilic molecules are suspected to use the transpiration stream as the driving force of entry (Abadía et al., 2011). Iron uptake by the leaves follows similar mechanisms as those described in the roots (Malhotra et al., 2019). Thus, even if strategies I and II remain essential pathways for iron acquisition by plants, they are not necessarily exclusive and may be complemented by additional mechanisms.

Iron is a central cofactor of enzymatic reactions involving electron transfer in essential metabolic pathways such as respiration or photosynthesis (Balk and Schaedler, 2014). Yet, its redox properties may also induce toxic effects. Free $\mathrm{Fe}^{2+}$ catalyzes the Fenton reaction in which reactive oxygen species (ROS) characteristic of oxidative stress are generated, and ROS may cause irreparable damage to cellular components when they are present in excessive concentrations (Winterbourn, 1995). The intracellular concentrations and forms of iron are therefore tightly regulated at the cellular level. The mechanisms involved in iron homeostasis have many common features in strategy I and strategy II plants (Connorton et al., 2017; Grillet and Schmidt, 2019; Kobayashi et al., 2019). In planta, chelation of $\mathrm{Fe}^{2+}$ to Nicotianamine (NA), and $\mathrm{Fe}^{3+}$ to citrate, allows iron mobilization and the control of its high reactivity (Curie et al., 2009; Connorton et al., 2017). In strategy II plants, ferric iron is additionally present in the form of $\mathrm{Fe}^{3+}$-PS (Zhang et al., 2019). Iron is also stored in unreactive forms such as ferritins that represent a major iron pool in plants mostly found in chloroplasts and mitochondria. They behave like a buffer that stores iron to avoid overload and the resulting ROS formation, and releases it when needed. To avoid oxidative stress, iron storage in vacuoles also contributes to iron homeostasis. Candidate transporters for moving cytosolic iron into vacuoles are members of the IRT, FPN/IREG (ferroportin/iron regulated) and VIT (vacuolar iron transporter) families (Morrissey et al., 2009; Roschzttardtz et al., 2009; Vert et al., 2009). VIT transporters are particularly important for vacuolar iron storage in seeds (Roschzttardtz et al., 2009; Zhang et al., 2012). In seeds, iron is mainly found under an insoluble form poorly available for nutrition because it is complexed with phosphate bound to inositol in phytates (Mary et al., 2015). Iron remobilization from the vacuoles is mediated by members of the natural resistanceassociated macro-phage protein family (NRAMP) (Curie et al., 2000; Nevo and Nelson, 2006). In addition to ferritins and vacuoles, the root apoplast appears as a third level of iron storage by plants (Curie and Mari, 2017). Bienfait et al. (1985) demonstrated that a pool of 500-1,000 nanomoles of Fe per gram fresh weight could be formed in the root apoplast where it is adsorbed on the cell wall whose net charge is negative (Shomer et al., 2003). The cell wall composition, more particularly the respective proportions of celluloses, hemicelluloses, pectins, and lignins, varies depending upon plant genotypes, and influences the amount of adsorbed iron (Chen, 2014; Shi et al., 2018). The plant capacity to store iron in its root apoplast is positively correlated to the amount of hemicelluloses in the cell wall and would be a key determinant in the IDC tolerance of graminaceous plant species such as maize (Shi et al., 2018). IDC tolerance in soybean is also associated with an increased amount of root apoplastic iron (Longnecker and Welch, 1990). Remobilization of precipitated apoplastic iron relies on phenolic compounds (Jin et al., 2007; Bashir et al., 2011; Ishimaru et al., 2011; Lei et al., 2014), putrescine synthesis, and decreased cell wall suberization (Zhu et al., 2016; Curie and Mari, 2017).

Proteins involved in iron acquisition-F6 ${ }^{\prime} \mathrm{H} 1$, PDR9, and members of the HA, FRO, and IRT family-also mediate cellular iron trafficking (Connorton et al., 2017). Members of the oligopeptide transporter (OPT) protein family (e.g., YS/YSL transporters) are also key determinants of iron transport in planta (Su et al., 2018; Grillet and Schmidt, 2019; Kumar et al., 2019). This transporter family is particularly important for the transport 
of Fe to the seeds (Grillet et al., 2014; Curie and Mari, 2017; Su et al., 2018; Kumar et al., 2019).

\section{Plant Breeding}

The identification of plant traits mediating plant iron uptake and iron homeostasis in planta offers opportunities for plant breeders to promote iron nutrition and content in agricultural products (Waters and Sankaran, 2011).

Conventional plant selection and new breeding strategies are both applied to enhance iron acquisition, storage and nutritional availability in edible parts of crops. There exists a natural genetic variation in the level of expression of the mechanisms regulating iron uptake and homeostasis among plant genotypes. The efficiency of plant iron nutrition is highly variable across plant species (Hansen et al., 2006). The level of tolerance or the susceptibility to IDC highly differs according to plant species and even to cultivars (e.g., Gildersleeve and Ocumpaugh, 1989; Zribi and Gharsalli, 2002; Mahmoudi et al., 2009; Helms et al., 2010). The Fe levels in grains can vary significantly depending on cultivars (e.g., from 10 to $160 \mathrm{mg} / \mathrm{kg}$ in maize, $15-360 \mathrm{mg} / \mathrm{kg}$ in wheat, $23-105 \mathrm{mg} / \mathrm{kg}$ in pea and 34-157 $\mathrm{mg} / \mathrm{kg}$ in bean) (White and Broadley, 2005, 2009). Assimilability of $\mathrm{Fe}$ for human beings correlates positively with the iron content in edible parts of crops (Welch et al., 2000) and varies with the forms of iron. The most assimilable forms of iron in plants are $\mathrm{Fe}^{2+}$-nicotianamine $\left(\mathrm{Fe}^{2+}-\mathrm{NA}\right)$ and $\mathrm{Fe}^{3+}$-ferritin (Zielińska-Dawidziak, 2015; Beasley et al., 2019). In addition, iron nutritional availability is decreased by antinutrient molecules (e.g., phytates and tannins) that hamper its assimilation. Sufficient iron availability in food products is only possible when the concentration of these molecules is low (Sandberg, 2002; Delimont et al., 2017). Conventional breeding has led to the selection of cultivars showing better resistance to iron stress (i.e., IDC tolerant) and a higher iron content in edible parts, but also a decreased content of antinutrients (reviewed in Garcia-Oliveira et al., 2018). This was the case in species displaying high natural variability in their iron content (e.g., bean and pearl millet) (Manwaring et al., 2016; Lockyer et al., 2018). The selection of IDC-tolerant cultivars has further improved yields under iron stress conditions. However, the corresponding selection process relies on a long and costly screening of inbred lines.

Taking that limitation into account, transgenesis has been proposed as an option to promote plant iron nutrition and content by overexpressing or silencing genes mediating plant iron acquisition, transport and/or storage. The corresponding strategy has been followed through the targeting of one gene or several ones in combination and has led to genotypes with an increased iron content (i.e., from $<2$ to 6-fold) (Kawakami and Bhullar, 2018; Connorton and Balk, 2019). However, transgenesis raises public concerns (Lassoued et al., 2018). Furthermore, positive effects recorded in controlled conditions may be lost in field conditions because iron bioavailability varies among soils (Gregory et al., 2017). For example, iron uptake by soybean was increased by overexpressing FRO in controlled iron stress conditions (Vasconcelos et al., 2006) but not in highcalcareous soil environments (Kocak, 2014); even more, this genetic transformation appeared to be deleterious under noniron stressed conditions due to toxic effects of the iron overload (Vasconcelos et al., 2006).

More generally, results from cultivars obtained from conventional and new breeding strategies vary depending upon soil iron bioavailability (Gregory et al., 2017; GarciaOliveira et al., 2018; Lockyer et al., 2018; Connorton and Balk, 2019). Alternative strategies based on QTL (quantitative trait loci) identification and on genome-wide association (GWAS) have been proposed to identify putative traits and genes mediating plant iron nutrition, and include them in plant breeding programs. The first step of this strategy confirmed the importance of genes implied in (i) iron uptake strategies I and II, (ii) the synthesis of phenolic compounds, and (iii) iron homeostasis. They further underlined the multigenic character of traits related to the plant iron status and the crucial importance of environmental conditions (Garcia-Oliveira et al., 2018; Connorton and Balk, 2019). Gene expression profiling of soybean plants sensitive or tolerant to IDC pinpointed key roles for phenylpropanoids (Waters et al., 2018). The major contribution of iron storage in the root apoplast and of fluorescent phenolics to remobilize this extracytoplasmic iron was confirmed and represents potential breeding targets (Curie and Mari, 2017; Waters et al., 2018). The complex and interregulated mechanisms of plant iron uptake and homeostasis has also been emphasized. A key role has been given to (i) phosphorus known to be in close relation with the iron status (e.g., Vansuyt et al., 2003; Tsai and Schmidt, 2017; Shi et al., 2018; Filiz and Kurt, 2019), (ii) ISR through the root-specific transcription factor MYB72 and beta-glucosidase BGLU42 (Zamioudis et al., 2014), and (iii) hormone signaling, especially IAA, Et, NO and ABA signaling (Lei et al., 2014; Li et al., 2015; Curie and Mari, 2017; Filiz and Kurt, 2019). The complex interrelations between the plant iron status, the P status, defense reactions and hormone signaling make the promotion of plant nutrition via plant breeding a difficult task.

\section{Plant-Microbe Interactions Mediating Iron Uptake and Homeostasis} Impact of Rhizosphere Microbiota on Iron Availability The rhizosphere microbiota impacts the physico-chemical properties of the root environment by acidifying the soil through the release of organic acids and protons, and chelating iron with organic acids and siderophores (Figure 1BD, 2). These modifications prompt iron extraction from the soil matrix and thus modify its solubility and availability for the host plant.

Solubilization of iron in the rhizosphere is promoted by acidification. Protons are released during microbial activities such as nitrification (Kuypers et al., 2018). Protons may also be released from carboxylic groups when the $\mathrm{pH}$ of the soil solution is higher than the $\mathrm{pKa}$ of organic acids exuded by microorganisms (Glasauer et al., 2003). The protons released by microbial and plant activities acidify the rhizosphere (Hinsinger et al., 2003; Norton and Ouyang, 2019). Iron initially bound in scarcely soluble minerals (e.g., hematites, goethites) and amorphous solids [e.g., $\mathrm{Fe}(\mathrm{OH})_{3}$ ] is replaced by protons at the sorption 
sites and released in the soil solution (Figure 1BO; AlbrechtGary and Crumbliss, 1998; Glasauer et al., 2003). Acidification also results from phosphate solubilization (Sharma A. et al., 2013). Organic acids are produced by rhizosphere bacteria that solubilize phosphates (e.g., Pseudomonas, Bacillus, Rhizobium, and Enterobacter) (Werra et al., 2009; Adeleke et al., 2017). Fe and $\mathrm{P}$ are often sequestered in soils together in low-solubility minerals like strengite or phosphosiderite. Thus, increased solubility of iron is associated with increased solubility of P (Marschner et al., 2011; Rijavec and Lapanje, 2016).

Solubilization of iron in the rhizosphere is also promoted by its chelation with organic acids, and by siderophores that scavenge ferric iron immobilized in scarcely soluble or insoluble forms and make it available to plants (Figure 1B2; Kraemer, 2004; Jin et al., 2010; Ferret et al., 2014). The great majority of aerobic microorganisms synthesize small molecules with a high affinity for ferric iron-called siderophores-for their nutrition in iron stress conditions. Microbial siderophores (MSs) present high but variable affinity for $\mathrm{Fe}^{3+}$, and are also diverse in size and chemical composition (Budzikiewicz, 2004; Hider and Kong, 2010; Saha et al., 2016; Khan et al., 2019). It has long been known that plants use iron chelated to MSs for their nutrition in Fe-limiting conditions; in particular, pyoverdines (pvds), a major class of siderophores produced by fluorescent pseudomonads, show a high affinity for ferric iron (reviewed by Crowley, 2006; Vansuyt et al., 2007; Jin et al., 2010; Shirley et al., 2011; Nagata et al., 2013; Radzki et al., 2013; Trapet et al., 2016). Rhizoferrin, ferrocrocin, fusigen, and coprogen, all produced by fungal root symbionts, also display high affinity for ferric iron (Winkelmann, 2017; Haselwandter et al., 2020). Microorganisms are expected to be highly competitive for $\mathrm{Fe}$ compared to plant roots because they can (i) use Fe bound to phytosiderophores (PSs) (microbial siderophores like pyoverdine have much higher affinity for Fe than PSs do), (ii) decompose PSs, and (iii) acquire iron more efficiently (Figure 1B11; Marschner et al., 2011; Sadrarhami et al., 2021). However, while Fepvds are more stable than Fe-PSs, they do not depress plant iron nutrition but, even more, promote it (Vansuyt et al., 2007; Jin et al., 2010; Shirley et al., 2011) in contrast with the early report of Becker et al. (1985b). The mechanisms underlying the beneficial effect of microbial siderophores on plant nutrition remain to be elucidated, even if some insights have been given (Vansuyt et al., 2007; Gonzàlez-Guerrero et al., 2016). Organic acids present much lower affinity for iron than siderophores do, but in circumneutral and alkaline environments such as calcareous soils, organic acids may be deprotonated and thus act as metal-complexing agents (Dehner et al., 2010). Hydrogen cyanide $(\mathrm{HCN})$ produced by microorganisms may also contribute to iron mobilization by chelation (Frey et al., 2010; Rijavec and Lapanje, 2016).

Availability of soil nutrients, including $\mathrm{Fe}$, can also be enhanced by increasing the volume of soil explored (Figure 1B(0). This is achieved by root fungal symbionts which greatly extend the scope of the roots through their fine hyphae. Increases in plant iron content have been ascribed to a better access to soil nutrients via fungal networks (Caris et al., 1998; Liu et al., 2000; Farzaneh et al., 2011). In addition, iron is transported into root cells by endosymbionts (Gonzàlez-Guerrero et al., 2016).

\section{Plant Iron Physiology Modulation by the Rhizosphere Microbiota}

Rhizosphere microorganisms modulate plant iron uptake mechanisms. The expression of genes involved in strategies I and II is modulated in the presence of microorganisms (Figure 1B6; Zhang et al., 2009; Nagata et al., 2013; Nagata, 2017; Kobae et al., 2014; Zhou et al., 2016, 2018; Wang et al., 2017; Kabir et al., 2020). Rhizosphere acidification and ferric reductase activity (implied in strategy I) and plant PS synthesis (implied in strategy II) are enhanced (Reza, 2017; Wang et al., 2017; Zhou et al., 2018; Prity et al., 2020). The production of plant phenolics known to impact plant iron uptake and remobilization (Figure 1B6; Fourcroy et al., 2016; Curie and Mari, 2017; Waters et al., 2018) and iron assimilability in food due to their antinutrient properties (Delimont et al., 2017) is also modified. Fluorescent pseudomonads induce the ISR (Van Loon et al., 2008; Berendsen et al., 2015) which regulates the expression of the root-specific transcription factor MYB72 and the MYB72-controlled beta-glucosidase BGLU42 (Zamioudis et al., 2014). These factors control the synthesis and excretion of iron-mobilizing FPCs in Arabidopsis (Palmer et al., 2013). Coumarins improve plant performance by eliciting microbeassisted iron nutrition (Harbort et al., 2020). The concentration and composition of phenolic compounds in edible parts of plants is regulated by associated microorganisms (e.g., Basha et al., 2006; Lavania et al., 2006; Baslam et al., 2011; Jain et al., 2014; Singh et al., 2014; Baker et al., 2015).

Microorganisms modulate plant hormone signaling, which in turn impacts the plant iron physiology by modulating iron acquisition and homeostasis (Figure 1B8; Lei et al., 2014; Li et al., 2015; Filiz and Kurt, 2019). Plant hormone signaling is under the control of microorganisms through the elicitation of the induced systemic response (ISR), a plant response interrelated with the plant iron deficiency response (Zamioudis et al., 2014; Romera et al., 2019). Changes in the plant indole acetic acid (IAA) and iron contents are observed concomitantly after bacterial inoculation, suggesting that microorganisms impact together hormone signaling and iron nutrition (Zhou et al., 2016, 2018; Housh et al., 2021). Emission of volatile organic compounds (VOCs) by Bacillus amyloliquefaciens promotes plant iron nutrition in Arabidopsis, and this promotion requires nitric oxide (NO) regulation (Wang et al., 2017), suggesting that the beneficial effect of the rhizosphere bacterial strain is regulated by plant hormone signaling. Rhizosphere microorganisms may either synthesize or degrade phytohormones [i.e., abscisic acid (ABA); IAA; gibberellic acid (GA); cytokinins (CKs); salicylic acid (SA); ethylene (Et); NO] and therefore modulate phytohormone concentrations (Horchani et al., 2011; Bakker et al., 2014; Egamberdieva et al., 2017; Ravanbakhsh et al., 2018). For example, the concentration of ethylene, a key regulator of root apoplastic iron remobilization under Fe shortage (Curie and Mari, 2017), is regulated by microbial 1-aminocyclopropane-1 carboxylic acid (ACC) deaminase that degrades the Et precursor (Ravanbakhsh et al., 2018). 
The influence of microorganisms on the plant antioxidant defense has been associated to an increase of the plant iron content in a series of studies performed on sorghum, sunflower and alfalfa (Figure 1B7; Kabir et al., 2020; Prity et al., 2020; Rahman et al., 2020). According to these authors, the promotion of ROS-scavenging activities by arbuscular mycorrhizal fungi (AMF) is part of the mechanisms involved in alleviation of Fe-deficiency symptoms.

Rhizosphere microorganisms can modify the plant iron status via their influence on the plant P status (Figure 1B9; Tsai and Schmidt, 2017; Shi et al., 2018; Filiz and Kurt, 2019). Phosphate solubilizers and AMF have long been described to promote plant P nutrition and growth (Brown, 1974; Smith et al., 2011). More recently, microbial promotion of $\mathrm{P}$ nutrition was showed to impact iron partitioning in the roots and shoots of Thypha angustifolia (Ghosh et al., 2014), and to enhance iron nutrition in chicory through an AMF (Glomus irregulare syn. Rhizophagus irregularis; Labidi et al., 2012).

Other activities of rhizosphere microorganisms may also influence iron storage in the root apoplast and its remobilization. The hemicellulose composition of the root cell wall influences the amount of stored Fe, while putrescine, a diamine excreted by the roots, is involved in the iron remobilization process (Figure 1; Zhu et al., 2016; Shi et al., 2018). Since cellulose and hemicellulose are degraded by microbial activities, iron storage in the root apoplast is likely to be impacted by the corresponding microorganisms (Figure 1B4; Lasa et al., 2019). Metatranscriptomic data indicate that the proportion of cellulose degraders is increased in the rhizosphere of cereals (Turner et al., 2013). Also, putrescine is one of the most commonly used substrate by wheat rhizosphere microorganisms (Gałązka et al., 2019): microbial degradation of this diamine (e.g., by pseudomonads) is thus likely to regulate plant remobilization of apoplastic iron (Kuiper et al., 2001; Song et al., 2015; Liu et al., 2018).

In sum, MSs play a key role in plant physiology related to iron uptake and homeostasis (Table 1 and Figures 1, 2) through (i) phosphorus solubilization and thus the plant P status (Sharma A. et al., 2013), (ii) elicitation of plant defense reactions through Microbial Associated Molecular Patterns (MAMPs) inducing ISR (De Vleesschauwer et al., 2006; Höfte and Bakker, 2007; Van Loon et al., 2008), (iii) plant hormone signaling and the synthesis of fluorescent root phenolics via ISR (Pieterse et al., 2014; Zamioudis et al., 2014), and (iv) the expression of genes mediating iron uptake and homeostasis (Table 1). The importance of microbial siderophores in the rhizosphere is also evidenced by results showing that their synthesis and activities are enhanced in the rhizosphere. Protein families related to siderophore production increased in barley root- and rhizosphere-associated bacterial taxa (Bulgarelli et al., 2015), and sequences encoding bacterial siderophore synthesis were highly enriched within bacterial endophytes in rice roots (Sessitsch et al., 2012).

In addition, discussion is running on the possible contribution of microbial siderophores to the remobilization of root apoplastic iron and in a non-reductive process of iron uptake by plants (Figure 1B3). A large-scale transcriptomic study in Arabidopsis suggests that remobilization of root apoplastic iron is promoted by the pyoverdine synthesized by $P$. fluorescens strain C7R12 (Trapet et al., 2016). Plants grown in iron-deficient conditions in the presence of apo-pyoverdine (a siderophore uncomplexed with iron) exhibited a phenotype similar to that of plants grown in iron-containing medium and incorporated more iron than the untreated plants did. In these conditions, pyoverdine repressed the expression of root genes related to ABA signaling (Trapet et al., 2016), suggesting that the MS may promote the remobilization of root apoplastic iron (which indeed implies ABA regulation) (Lei et al., 2014; Curie and Mari, 2017). Possible non-reductive uptake of bacterial ferrisiderophores would represent an additional and major influence of microorganisms on the plant iron status. Various findings support the existence of a transport system whereby the plant would internalize bacterial ferrisiderophores in the form of integral ferric chelates. Pyoverdines of fluorescent pseudomonads chelated to iron $\left(\mathrm{Fe}^{3+}-\mathrm{pvd}\right)$ contribute to the plant iron nutrition of both dicots (strategy I) and graminaceous monocots (strategy II) more efficiently than the synthetic ferric chelate $\mathrm{Fe}^{3+}$-EDTA does (Vansuyt et al., 2007; Jin et al., 2010; Shirley et al., 2011). The stability constant of the $\mathrm{Fe}^{3+}$-pvd complex is significantly higher $\left(10^{32}\right)$ than that of $\mathrm{Fe}^{3+}$-EDTA $\left(10^{25}\right)$ or Fe-PS $\left(10^{18}\right.$ ) (Vansuyt et al., 2007; Shirley et al., 2011). This suggests that dissociation and ligand exchange between $\mathrm{Fe}^{3+}$-pvd and $\mathrm{Fe}^{3+}$-PS might not be the sole process accounting for the enhanced iron nutrition by $\mathrm{Fe}$ MS and suggests incorporation of $\mathrm{Fe}^{3+}$-pvd by the roots. The presence of pvd in planta was confirmed by measurements of ${ }^{15} \mathrm{~N}$-labeled $\mathrm{Fe}^{3+}$-pvd and by immunodetection using antipyoverdine antibodies (Vansuyt et al., 2007; Trapet et al., 2016). The use of IRT1 knock-out mutants indicated that this membrane transporter of $\mathrm{Fe}^{2+}$ (IRT1) is not involved in iron uptake from $\mathrm{Fe}^{3+}$-pvd in strategy I plants (Vansuyt et al., 2007). Thus, Fe-pvd clearly contributes to plant iron nutrition, with evidence of the presence of pvd in planta but no proof of the direct uptake of the entire $\mathrm{Fe}^{3+}$-pvd complex. The description of a non-reductive iron uptake system in a phytoplankton organism supports a possible incorporation of bacterial ferrisiderophores kept throughout evolution (Kazamia et al., 2018). This hypothesis is also supported by the presence of vesicles in the roots of Arabidopsis supplemented with Fe-pvd (Lemanceau et al., 2009); these vesicles mediate the internalization of ferrisiderophores by endocytosis in diatoms (Kazamia et al., 2018).

\section{Plant-Plant-Microbe Interactions Mediating Plant Iron Nutrition and Homeostasis}

The plant iron status is modulated by plant-plant interactions that also involve microbial interactions in non-sterile growing conditions. Intercropping, in which at least two plant species are grown together in the same field, is proposed as a means to increase crop yield and quality in low-input agricultural systems by valuing beneficial plant-plant interactions. Several studies 


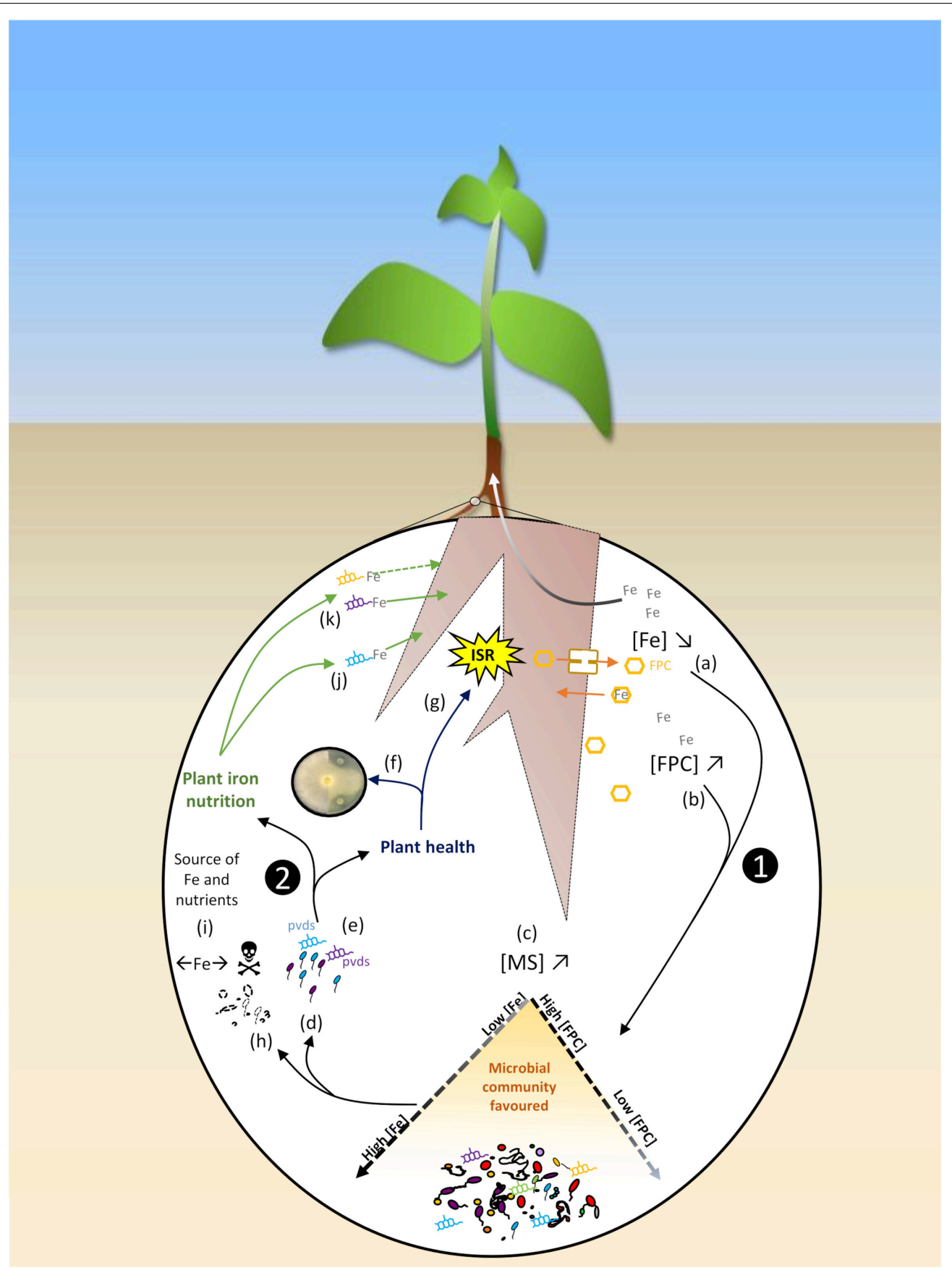

FIGURE 2 | Schematic representation of the feedback loop summarizing the iron dynamics in the rhizosphere as regulated by plant-microbe interactions. $\mathbf{0}$ The plant iron status shapes the rhizosphere microbiota. Iron bioavailability ([Fe] $\searrow$ ) is decreased in the rhizosphere due to plant Fe uptake (a) (Robin et al., 2006, 2007), and plant excretion of root fluorescent phenolic compounds (FPCs) is enhanced in calcareous soils ([FPC] $\nearrow$ ), with low iron availability ([Fe] $\backslash$ ) (b) (Jin et al., 2010; Stringlis et al., 2018). Production of microbial siderophores is consequently increased ([MS] $\nearrow$ ) (c) (Jin et al., 2010), and pseudomonads adapted to iron stresss conditions are favored (d) (Robin et al., 2007) thanks to the synthesis of specific pyoverdines (pvds) (e) (Robin et al., 2007; Stringlis et al., 2018). (2In return, these populations positively influence plant health and iron nutrition. Specific pvds of rhizosphere pseudomonads display high antagonistic activities by competing against phytopathogens for iron (f) (Robin et al., 2007; Gu et al., 2020), and others trigger plant induced systemic resistance (ISR) (g) (Stringlis et al., 2018). Fungal phytopathogens (Fusarium) can be counter-selected by FPCs (h) (Stringlis et al., 2018). Specific microbial populations are counter-selected by iron competition $(\leftarrow \mathrm{Fe} \rightarrow)$, by FPC toxicity $(\stackrel{*}{*})$, or microbial antagonism; these populations represent a source of iron (and of other nutriments) when metabolized (i). A siderophore produced by a pseudomonad strain recruited in the rhizosphere of an iron-stressed plant can also favor plant iron nutrition (j) (Jin et al., 2010), and distinct pvds of different strains of Pseudomonas differently favor plant iron nutrition (K) (Lurthy et al., 2020), suggesting that plant iron nutrition is impacted differently depending on the pseudomonads recruited in the rhizosphere. 
reviewed by Xue et al. (2016) and Dai et al. (2019) reported increased tolerance to IDC of legumes and non-legume dicots in alkaline conditions when they were associated with a cereal in intercropping systems. Intercropping can also modulate plant iron distribution (Xue et al., 2016). Intercropping with grass was even more efficient than adding iron chelates on the yields of blueberries cultivated in sub-alkaline soil (Michel et al., 2019). An increased iron content of peanut grains (1.43-fold) was recorded when peanut was intercropped with maize in calcareous soil (Zuo and Zhang, 2009). Intercropping with oat was as good as in-furrow amendment with chemical Fe chelate (FeDDHA) for alleviating soybean IDC on calcareous soils (Kaiser et al., 2014). However, variations were observed depending on environmental conditions, and Fe amendment was sometimes more reliable. Better knowledge of the biotic interactions involved is therefore required to increase the reproducibility of the results so as to develop these environmentally friendly cropping systems.

Regarding iron uptake, three mechanisms of facilitation may account for the enhancement of iron nutrition in dicots in the presence of graminaceous crop plants.

The first mechanism would rely on the extraction of iron by chelation with PSs from grasses that would increase iron availability to dicots, as shown when intercropping olive (Cañasveras et al., 2014) and citrus rootstocks (Cesco et al., 2006) with grasses. Intercropping impacted PS production and expression of the FRO and IRT genes implied in the strategy I iron uptake system. However, this trend lacks consistency across studies (Dai et al., 2019).

A second mechanism would rely on a non-reductive mechanism used by dicots to incorporate Fe-PSs formed with PSs excreted by grasses. Fe-PSs from a strategy II plant (maize) were internalized by a strategy I plant (peanut) (Xiong et al., 2013) via a membrane transporter belonging to the YS/YSL family of Fe-PS transporters (Curie et al., 2000, 2009).

Finally, the third mechanism enhancing iron uptake in dicots intercropped with maize would rely on the remobilization of apoplastic iron by root phenolic compounds. Under Fe deficiency, maize was unable to remobilize its pool of root apoplastic iron, contrary to bean (Bienfait et al., 1985). In addition, Fe-deficient bean plants mobilized iron from the root apoplast of other plants grown in their presence (Bienfait et al., 1985). In alkaline conditions, increased synthesis of root fluorescent phenolics (Waters et al., 2018) could contribute to the mobilization of rhizosphere iron by dicots. Therefore, the non-used root apoplastic iron pool of maize roots could be remobilized by an associated dicotyledonous crop. This could partly account for the better iron nutrition of legumes grown together with maize (Xue et al., 2016; Dai et al., 2019).

The rhizosphere microbiota also contributes to the better efficiency of plant species cultivated together. In cereal-legume intercropping, symbiotic interactions between the legume species and nitrogen-fixing microorganisms decrease competition for soil nitrogen, and the resulting resource partitioning promotes nitrogen nutrition of the cereal. In addition to limited interspecific competition for $\mathrm{N}$ acquisition in cereal-legume intercropping, other processes such as soil $\mathrm{N}$ enrichment or high $\mathrm{N}$ restitution through below-ground legume residues benefit $\mathrm{N}$ acquisition by the cereal (Hauggaard-Nielsen et al., 2009; Fustec et al., 2010). More generally, plant-plant interactions impact root exudation, and this affects soil rhizosphere microbiota (Vora et al., 2021) and favors colonization by AMF (Ingraffia et al., 2019). On the other hand, improved mycorrhization increased the Fe content in wheat intercropped with faba bean, but did not increase it in mono-cropped faba bean (Ingraffia et al., 2019). According to these authors, the enhancement of plant Fe uptake modulated by AMF depends on soil physico-chemical properties. The mycorrhizosphere of associated plants, formed by AMFcolonized roots and hyphae, increases microbiota functionalities (Wahbi et al., 2016b). Intercropping impacts the abundance, diversity, activity and co-occurrence network of rhizosphere microbial communities (Li et al., 2016, 2018; Wahbi et al., 2016a; Duchene et al., 2017; Taschen et al., 2017; Gao et al., 2019; Zaeem et al., 2019; Liu et al., 2021; Pivato et al., 2021). This is in agreement with the well-known positive relationship between plant and microbial diversity (Spehn et al., 2000; Carney and Matson, 2005; Qiao et al., 2012; Ahmad et al., 2013). In controlled conditions, the pea-wheat association did not harbor a mixture of the two rhizospheres, but rather a new bacterial community with more Actinobacteria and a decreased abundance of $\alpha$-Proteobacteria and Acidobacteria (Taschen et al., 2017). In another study in field conditions, bacterial networks were impacted by pea-wheat intercropping, but bacterial diversity and structure were not, suggesting a more complex bacterial network and more complex interactions (Pivato et al., 2021). The observed changes in the microbial community diversity and its increased complexity may account for the beneficial effects observed in intercropping. Compared to maize and peanut cultivated independently, comparable microbial communities have been observed whether the roots were separated or not: Bacillus, Brevibacillus, and Paenibacillus were mainly increased in the rhizosphere of maize, while Burkholderia, Pseudomonas, and Rhizobium were mainly increased in the rhizosphere of peanut. In these conditions, the availability of nutrients ( $\mathrm{N}$ and P) was increased (Li et al., 2018), even if no correlation was found with the changes observed in the microbial community.

More generally, the higher microbial diversity associated with higher plant diversity results in better plant fitness, resilience to stress (De Vries et al., 2018), and positive effects of intercropping (Sun et al., 2009). Various studies suggesting a better iron nutrition of strategy I plants grown in association with a cereal have been reported (reviewed by Xue et al., 2016; Dai et al., 2019). Despite the well-known impact of intercropping on the rhizosphere microbiota and evidence of the role of microorganisms (e.g., AMF) in enhancing plant nutrition in association, data allowing us to evaluate the role played by the plant microbiota are missing. Additional data on the plant iron content will also be required because up to now the effect of intercropping has been mostly evaluated by visually recording IDC symptoms. Therefore, knowledge integrating plant-plant, plant-microorganism and microbemicrobe interactions is sorely lacking. 


\section{CONSEQUENCES FOR THE DEVELOPMENT OF IRON BIOFORTIFICATION STRATEGIES}

Microorganisms modulate iron bioavailability nearby and within the roots, as weel as plant iron uptake and homeostasis (Figure 1). Optimizing the biotic interactions that mediate plant iron uptake and homeostasis opens onto stimulating prospects for plant iron biofortification. The importance of microorganisms in plant nutrition including iron nutrition is widely acknowledged, but up to now they have been mainly used as biofertilizers and applied to plants in different formulations containing one or several microorganisms. However beneficial effects of microbial inoculation are often offset by a lack of consistency due to poor survival of the introduced strains (Singh and Prasanna, 2020; French et al., 2021).

Current research is now shifting its focus on the monitoring of rhizosphere microbiota on the basis of increasing knowledge of the plant-microbe feedback. The impact of the rhizosphere microbiota on iron availability and plant iron physiology is part of dynamic processes that are themselves influenced by plantmicrobe interactions. Monitoring plant-microbe interactions mediating plant iron nutrition and homeostasis requires to decipher the complexity of the corresponding interactions. It is now well established that plants shape the composition of their microbiota via rhizodeposition including root exudation (Badri et al., 2013; Lemanceau et al., 2017a; Canarini et al., 2019; Jones et al., 2019). In turn, the rhizosphere microbiota impacts plant nutrition, growth and health. This feedback loop is modulated by the plant genotype and by the soil physicochemical and biological properties (Lemanceau et al., 2017b; Rodriguez et al., 2019). These reciprocal interactions are well illustrated by the iron dynamics in the rhizosphere (Figure 2). Two series of studies report that the Fe-chelating ability of the rhizosphere microbiota is modified by the plant iron status. The first one was conducted on transgenic tobacco deregulated in ferritin, hence hyperaccumulation of iron in planta and iron depletion of the corresponding rhizosphere. This depletion resulted in the selection of pseudomonad populations highly adapted to iron-stressed conditions thanks to the synthesis of efficient siderophores (Robin et al., 2006, 2007). The second series was conducted with clover grown in Fe-deficient conditions; this plant synthesized more phenolic compounds, hence the selection of a higher occurrence of siderophoreproducing bacteria (Jin et al., 2010). In both cases, the plant contributed to decrease rhizosphere iron availability. This led to an increased level of iron competition that favored the microbial communities most adapted to these iron stress conditions thanks to their siderophores (Figure 2; Robin et al., 2006, 2007; Jin et al., 2007, 2010), while depleting those susceptible to low iron availability. The plant metabolites released in iron stress conditions (e.g., phenolic compounds like scopoletin) may even have a biocidal effect on susceptible populations (Gnonlonfin et al., 2012). Microbial populations recruited by the host plant in turn impact plant nutrition, growth, and health (Figure 2). Thus, plant iron nutrition was promoted by siderophores synthesized by a Pseudomonas strain originating from the rhizosphere of $\mathrm{Fe}$-deficient clover (Jin et al., 2010). Also, a siderophore from a pseudomonad strain highly represented in the rhizosphere of a pea cultivar tolerant to IDC significantly improved iron nutrition of this plant (Lurthy et al., 2020). Similarly, two strains ( $P$. simiae WCS417 and P. capeferrum WCS358) highly tolerant to the antimicrobial effect of root phenolics promoted Arabidopsis growth via siderophore production (Figure 2; Berendsen et al., 2015; Stringlis et al., 2018). The biomass of the microbes counter-selected by iron competition and phenolics represents a potential pool of iron and other nutrients. Thus, in addition to iron stored in ferritins, vacuoles and the root apoplastic compartment, the root microbiota could be used as an additional level of iron storage by plants. Regarding plant health, major phytopathogens are controlled by iron competition in the rhizosphere. Siderophores with a high affinity for iron and retrieved from the rhizosphere of ferritin-overexpressing transgenic tobacco displayed a higher antagonistic activity against the phytopathogenic oomycete Pythium aphanidermatum (Figure 2; Robin et al., 2007). Root FPCs synthesized through a MYB72-dependent pathway selectively inhibited the soil-borne fungal pathogens Fusarium oxysporum and Verticillium dahlia (Figure 2; Stringlis et al., 2018). In addition, plant protection was promoted by the above mentioned P. simiae WCS417 and $P$. capeferrum WCS358, inducers of plant systemic resistance (ISR; Stringlis et al., 2018).

The influence of the crosstalk between the host plant and its associated microbiota on plant iron nutrition (Figure 2) stresses the importance of considering the plant together with its microbiota in biofortification strategies. Progress in the knowledge of the interactions between eukaryotic organisms and their associated microbiota has led to the emergence of the holobiont concept, defined as the host and its associated microbes (Vandenkoornhuyse et al., 2015). Because of the importance of their associated microbiota, in terms of abundance, diversity and beneficial effects for the host plant, plants can no longer be considered as stand-alone entities (Dessaux et al., 2016). According to this concept, the genome interacting with its environment is no more restricted to the plant genome but is extended to that of the holobiont (hologenome) (Theis et al., 2016). Therefore, we propose to consider holobiont genetic resources for improving the plant iron status. Including the plant microbiota and its transmission by seeds in breeding programs has been proposed (Gopal and Gupta, 2016; Wei and Jousset, 2017; Berg and Raaijmakers, 2018). More recently, Wille et al. (2019) presented a comprehensive review of the plant-microbe interactions implied in resistance to root diseases in grain legumes and discussed possible consequences for breeding strategies. They especially proposed to consider the entire plant holobiont in resistance breeding strategies. The same principle should be applied to iron biofortification. In that prospect, plant traits included in breeding programs should comprise traits modulating plant-microbe interactions beneficial for the plant iron status. These traits represent promising new breeding targets. Among them, three types stand out and require special attention (i) the synthesis pathways of fluorescent phenolics and plant defense responses sharing 
common key components, (ii) plant regulation of iron storage in the root apoplast, and (iii) putrescine synthesis mediating apoplastic iron remobilization. The targeted plant traits should also include those involved in the recruitment of functional microbial genes (Lemanceau et al., 2017b) mediating siderophore production, synthesis, or degradation of specific molecules related to the plant iron physiology (e.g., cellulose, hemicellulose, putrescine, plant hormones). Particular attention should be paid to microbial siderophores because they represent a major contribution of microorganisms to the plant iron status, although the mechanisms involved are not all known yet. Recent results show that effects of Fe-MS on the plant iron status vary depending on plant genotype and MS structure (Lurthy et al., 2020). Therefore, the high level of specificity between the plant and its microbiota should be taken into account. Beyond plantmicroorganism interactions, crop biodiversity and plant-plant interactions represent major levers for improving the resistance and resilience of canopies and reducing their dependence on synthetic inputs, to ultimately ensure crop sustainability (Wezel et al., 2014; Dubey et al., 2020). Increasing crop biodiversity relies on the association of plants cultivated in intercropping. The challenge is to find out plant associations and practices that favor processes of ecological facilitation in intecropping. This occurs when the association optimizes the development of both species (e.g., improved resource availability) and minimizes any negative interactions that might occur between the two species (Callaway, 1995). To allow this facilitation process to occur and thus promote the functioning and performance of intercropping, the choices of plant species and cultivars to be grown in association, together with the cropping practices (seeding density and pattern, level of nitrogen fertilization) are key to success (Andersen et al., 2007; Neumann et al., 2007; Bedoussac et al., 2015). When these conditions are met, intercropping allows better nutrition of each associated plant species thanks to the facilitation process (Duchene et al., 2017) and the use of fertilizers can be reduced (Bedoussac and Justes, 2010). Research is ongoing to optimize biotic interactions that promote plant nutrition. Given the impact of the plant species, but also of its genotype, on the rhizosphere microbiota, characterizing the effect of different cultivars of a plant species grown in association on the microbial community is a key step for identifying the best performing cultivars in the association. However, the mechanisms underlying the positive effects of these cropping systems on plant-microbe interactions remain largely untapped, and further studies are required to better understand and exploit the interplay of these biotic interactions.

\section{CONCLUSION AND PROSPECTS}

Iron amounts in soils are above plant needs but are not readily available in most agricultural soils. Consequently, increasing soil iron bioavailability to enhance plant and ultimately human nutrition represents a major challenge. The soil microbiota has a great impact on iron bioavailability in the rhizosphere and on plant iron physiology. This should open avenues for plant iron biofortification strategies that will value these biotic interactions. The entire plant holobiont should be considered in biofortification strategies, and the plant traits included in breeding programs should comprise traits modulating plantmicrobe interactions beneficial for the plant iron status. These traits will include the synthesis of root phenolics and the regulation of apoplastic iron storage and remobilization. Plant traits mediating the recruitment of microbial genes involved in the synthesis or degradation of specific molecules related to the plant iron physiology (e.g., cellulose, hemicellulose, putrescine, plant hormones) have to be investigated. Special attention should be paid to the interactions with microbial siderophores, which strongly impact the plant iron status; many of the mechanisms involved still have to be identified. Recent findings highlight the specificity of biotic interactions, the role of the environment, and the interconnexion between plant iron nutrition and other parameters that also influence the quantity and the quality of vegetal products - plant health, the $\mathrm{P}$ status, and the ionome. This leads us to think that important headways should be made possible by the development of integrative approaches. In addition to iron biofortification, these approaches will take into account plants and their extended genotype formed by each plant and its specific microbiota; this holobiotic organism will be more prone than the plant alone to adapt to environmental stresses. Intercropping appears promising to implement these strategies.

More options for iron biofortification could be brought by emerging research perspectives. Most of the findings on the microbial influence on plant iron come from studies focusing on soil and rhizosphere interactions. Yet, the phyllosphere and spermosphere microbiota, whose influence has long been underestimated, also influence the plant iron physiology (Lemanceau et al., 2017a). Iron is absorbed by the leaves, and a signal originating from the shoots and involving IAA appears to elicit root-to-shoot iron translocation (Kabir et al., 2013; Garnica et al., 2018). The importance of the shoot microbiota on these components of the plant iron dynamics remains to be explored. The spermosphere microbiota is at least partly inherited from parent plants (Lemanceau et al., 2017a). Therefore, it is essential to evaluate the role of the corresponding microorganisms. Studies on the plant microbiota mostly provide taxonomic descriptions of plant-associated microorganisms. Therefore, results are deeply influenced by the soil microbiota reservoir which varies according to the soil physical and chemical properties (Dequiedt et al., 2009; Ranjard et al., 2013; Xue et al., 2018). Lemanceau et al. (2017b) have proposed the principle of a functional plant-genotype-specific core microbiota shared whatever the soil in which the corresponding genotype is cultivated. This proposal relies on the fact that plant-beneficial microbial traits (e.g., production of siderophores, hormones, antibiotic molecules, and $\mathrm{HCN}$ ) can be found in distinct microbial taxa. Finally, it is important to widen the objectives and develop more integrative studies. Potential trade-offs may indeed occur. Breeding programs focused on plant health promotion could be detrimental to plant growth and also impact the plant iron status, and vice versa. The dynamics of iron in the rhizosphere also modulates plant health (Figure 2). Seemingly, increasing plant iron content also more globally impacts the 
plant ionome (Cohen et al., 1998). This could be favorable to other essential micronutrients like $\mathrm{Zn}$, but could also lead to the accumulation of toxic elements due to the variable specificity of plant iron transporters (Rajkumar et al., 2010; De Valença et al., 2017). Another trade-off probably involves phenolic antioxidant compounds. Research about them is ongoing for improving human health, but they may also act as antinutrients by decreasing iron assimilability. The selection of new genotypes should no longer be oriented toward the production of plants harboring specific characters like enhanced iron content or resistance to a given pathogen. Plant improvement strategies should rather consider the extended genotype formed by the plant and its specific microbiota, and search for combinations allowing the holobiont to quickly adapt to a range of severe biotic and abiotic stresses likely to occur for a particular crop. We should rather tend toward the search for "ideoholotypes."

\section{REFERENCES}

Abadía, J., Vázquez, S., Rellán-Álvarez, R., El-Jendoubi, H., Abadía, A., AlvarezFernández, A., et al. (2011). Towards a knowledge-based correction of iron chlorosis. Plant Physiol. Biochem. 49, 471-482. doi: 10.1016/j.plaphy.2011.01. 026

Adeleke, R., Nwangburuka, C., and Oboirien, B. (2017). Origins, roles and fate of organic acids in soils: a review. S. Afr. J. Bot. 108, 393-406. doi: 10.1016/j.sajb. 2016.09.002

Ahmad, I., Cheng, Z., Meng, H., Liu, T., Wang, M., Ejaz, M., et al. (2013). Effect of pepper-garlic intercropping system on soil microbial and bio-chemical properties. Pak. J. Bot. 45, 695-702.

Aisen, P., Enns, C., and Wessling-Resnick, M. (2001). Chemistry and biology of eukaryotic iron metabolism. Int. J. Biochem. Cell. Biol. 33, 940-959. doi: 10.1016/s1357-2725(01)00063-2

Albrecht-Gary, A. M., and Crumbliss, A. L. (1998). Coordination chemistry of siderophores: thermodynamics and kinetics of iron chelation and release. Met. Ions Biol. Syst. 35, 239-327.

Andersen, M. K., Hauggaard-Nielsen, H., Høgh-Jensen, H., and Jensen, E. S. (2007). Competition for and utilisation of sulfur in sole and intercrops of pea and barley. Nutr. Cycl. Agroecosyst. 77, 143-153. doi: 10.1007/s10705-0069053-7

Badri, D. V., Chaparro, J. M., Zhang, R., Shen, Q., and Vivanco, J. M. (2013). Application of natural blends of phytochemicals derived from the root exudates of Arabidopsis to the soil reveal that phenolic-related compounds predominantly modulate the soil microbiome. J. Biol. Chem. 288, 4502-4512. doi: $10.1074 /$ jbc.M112.433300

Bailey, R. L., West, K. P. W. Jr., and Black, R. E. (2015). The epidemiology of global micronutrient deficiencies. Ann. Nutr. Metab. 66, 22-33. doi: 10.1159/ 000371618

Baker, C. J., Mock, N. M., Smith, J. M., and Aver'Yanov, A. A. (2015). The dynamics of apoplast phenolics in tobacco leaves following inoculation with bacteria. Front. Plant. Sci. 6:649. doi: 10.3389/fpls.2015.00649

Bakker, P. A. H. M., Ran, L., and Mercado-Blanco, J. (2014). Rhizobacterial salicylate production provokes headaches! Plant Soil 382, 1-16. doi: 10.1007/ s11104-014-2102-0

Balk, J., and Schaedler, T. A. (2014). Iron cofactor assembly in plants. Annu. Rev. Plant Biol. 65, 125-153. doi: 10.1146/annurev-arplant-050213-035759

Bar-Ness, E., Hadar, Y., Chen, Y., Römheld, V., and Marschner, H. (1992). Iron uptake by plants from microbial siderophores: a study with 7-nitrobenz-2 oxa1,3-diazole-desferrioxamine as fluorescent ferrioxamine B analog. Plant Physiol. 99, 1329-1335. doi: 10.1104/pp.99.4.1329

Basha, S. A., Sarma, B. K., Singh, D. P., Annapurna, K., and Singh, U. P. (2006). Differential methods of inoculation of plant growth-promoting rhizobacteria induce synthesis of phenylalanine ammonia-lyase and phenolic compounds differentially in chickpea. Folia Microbiol. (Praha). 51, 463-468. doi: 10.1007/ bf02931592

\section{AUTHOR CONTRIBUTIONS}

SM and PL initiated the review. All authors contributed and approved the final manuscript.

\section{FUNDING}

This work was supported by the POSiTiF project of the Plant2Pro Carnot Institute and by the "Conseil Régional de Bourgogne".

\section{ACKNOWLEDGMENTS}

We are grateful to Annie Buchwalter for correcting the English text.

Bashir, K., Ishimaru, Y., and Nishizawa, N. K. (2010). Iron uptake and loading into Rice Grains. Rice. 3, 122-130. doi: 10.1007/s12284-010-9042-y

Bashir, K., Ishimaru, Y., Shimo, H., Kakei, Y., Senoura, T., Takahashi, R., et al. (2011). Rice phenolics efflux transporter 2 (PEZ2) plays an important role in solubilizing apoplasmic iron. J. Soil. Sci. Plant. Nutr. 57, 803-812. doi: 10.1080/ 00380768.2011.637305

Baslam, M., Garmendia, I., and Goicoechea, N. (2011). Arbuscular mycorrhizal fungi (AMF) improved growth and nutritional quality of greenhouse-grown lettuce. J. Agr. Food. Chem. 59, 5504-5515. doi: 10.1021/jf200501c

Beasley, J. T., Hart, J. J., Tako, E., Glahn, R. P., and Johnson, A. A. T. (2019). Investigation of nicotianamine and 2' deoxymugineic acid as enhancers of iron bioavailability in caco-2 cells. Nutrients. 11:1502. doi: 10.3390/nu11071502

Beck, K. L., Conlon, C. A., Kruger, R., and Coad, J. (2014). Dietary determinants of and possible solutions to iron deficiency for young women living in industrialized countries: a review. Nutrients. 6, 3747-3776. doi: 10.3390/ nu6093747

Becker, J. O., Hedges, R. W., and Messens, E. (1985b). Inhibitory effect of pseudobactin on the uptake of iron by higher plants. Appl. Environ. Microbiol. 49, 1090-1093. doi: 10.1128/aem.49.5.1090-1093.1985

Becker, J. O., Messens, E., and Hedges, R. W. (1985a). The influence of agrobactin on the uptake of ferric iron by plants. FEMS Microbiol. Ecol. 31, 171-175. doi: 10.1111/j.1574-6968.1985.tb01145.x

Bedoussac, L., and Justes, E. (2010). The efficiency of a durum wheat-winter pea intercrop to improve yield and wheat grain protein concentration depends on $\mathrm{N}$ availability during early growth. Plant Soil 330, 19-35. doi: 10.1007/s11104009-0082-2

Bedoussac, L., Journet, E.-P., Hauggaard-Nielsen, H., Naudin, C., Corre-Hellou, G., Jensen, E. S., et al. (2015). Ecological principles underlying the increase of productivity achieved by cereal-grain legume intercrops in organic farming. A review. Agron. Sustain. Dev. 35, 911-935. doi: 10.1007/s13593-014-0277-7

Berendsen, R. L., van Verk, M. C., Stringlis, I. A., Zamioudis, C., Tommassen, J., Pieterse, C. M., et al. (2015). Unearthing the genomes of plant-beneficial Pseudomonas model strains WCS358, WCS374 and WCS417. BMC Genomics 16:539. doi: 10.1186/s12864-015-1632-z

Berg, G., and Raaijmakers, J. M. (2018). Saving seed microbiomes. Int. Soc. Microbial. Ecol. J. 12, 1167-1170. doi: 10.1038/s41396-017-0028-2

Bienfait, H. F., Briel, W., and van den Mesland-Mul, N. T. (1985). Free space iron pools in roots: generation and mobilization. Plant Physiol. 78, 596-600. doi: 10.1104/pp.78.3.596

Briat, J.-F., Dubos, C., and Gaymard, F. (2015). Iron nutrition, biomass production, and plant product quality. Trends Plant Sci. 20, 33-40. doi: 10.1016/j.tplants. 2014.07.005

Brown, M. E. (1974). Seed and root bacterization. Annu. Rev. Phytopathol. 12, 181-197. doi: 10.1146/annurev.py.12.090174.001145

Budzikiewicz, H. (2004). Siderophores of the Pseudomonadaceae sensu stricto (fluorescent and non-fluorescent Pseudomonas spp.). Fortschr. Chem. Org. Naturst. 87, 81-237. doi: 10.1007/978-3-7091-0581-8_2 
Bulgarelli, D., Garrido-Oter, R., Münch, P. C., Weimn, A., Dröge, J., Pan, Y., et al. (2015). Structure and function of the bacterial root microbiota in wild and domesticated barley. Cell Host Microbe 17, 392-403. doi: 10.1016/j.chom.2015. 01.011

Callaway, R. M. (1995). Positive interactions among plants. Bot. Rev. 61, 306-349. doi: 10.1007/BF02912621

Canarini, A., Kaiser, C., Merchant, A., Richter, A., and Wanek, W. (2019). Root exudation of primary metabolites: mechanisms and their roles in plant responses to environmental stimuli. Front. Plant. Sci. 10:157. doi: 10.3389/fpls. 2019.00157

Cañasveras, J. C., del Campillo, M. C., Barrón, V., and Torrent, J. (2014). Intercropping with grasses helps to reduce iron chlorosis in olive. J. Soil Sci. Plant. Nutr. 14, 554-564. doi: 10.4067/S0718-95162014005000044

Caris, C., Hördt, W., Hawkins, H. J., Römheld, V., and George, E. (1998). Studies of iron transport by arbuscular mycorrhizal hyphae from soil to peanut and sorghum plants. Mycorrhiza 8, 35-39. doi: 10.1007/s005720050208

Carney, K. M., and Matson, P. A. (2005). Plant communities, soil microorganisms, and soil carbon cycling: does altering the world belowground matter to ecosystem functioning? Ecosystems 8, 928-940. doi: 10.1007/s10021-0050047-0

Carrillo-Castañeda, G., Muñoz, J. J., Peralta-Videa, J. R., Gomez, E., and Gardea-Torres, J. L. (2005). Modulation of uptake and translocation of iron and copper from root to shoot in common bean by siderophoreproducing microorganisms. J. Plant. Nutr. 28, 1853-1865. doi: 10.1080/ 01904160500251340

Cesco, S., Rombolà, A. D., Tagliavini, M., Varanini, Z., and Pinton, R. (2006). Phytosiderophores released by graminaceous species promote $59 \mathrm{Fe}$-uptake in citrus. Plant Soil 287, 223-233. doi: 10.1007/s11104-006-9069-4

Chen, H. (2014). "Chemical composition and structure of natural lignocellulose," in Biotechnology of Lignocellulose: Theory And Practice, ed. H. Chen (Dordrecht: Springer), 25-71. doi: 10.1007/978-94-007-6898-7_2

Chen, L., Dick, W. A., and Streeter, J. G. (2000). Production of aerobactin by microorganisms from a compost enrichment culture and soybean utilization. J. Plant. Nutr. 23, 2047-2060. doi: 10.1080/019041600093 82164

Chen, Y., and Barak, P. (1982). Iron nutrition of plants in calcareous soils. $A d v$. Agron. 35, 217-240. doi: 10.1016/S0065-2113(08)60326-0

Clark, R. B., and Zeto, S. K. (1996). Mineral acquisition by mycorrhizal maize grown on acid and alkaline soil. Soil Biol Biochem. 28, 1495-1503. doi: 10.1016/ S0038-0717(96)00163-0

Cohen, C. K., Fox, T. C., Garvin, D. F., and Kochian, L. V. (1998). The role of irondeficiency stress responses in stimulating heavy-metal transport in plants. Plant Physiol. 116, 1063-1072. doi: 10.1104/pp.116.3.1063

Colombo, C., Palumbo, G., He, J.-Z., Pinton, R., and Cesco, S. (2014). Review on iron availability in soil: interaction of Fe minerals, plants, and microbes. J. Soil. Sedim. 14, 538-548. doi: 10.1007/s11368-013-0814-z

Connorton, J. M., and Balk, J. (2019). Iron biofortification of staple crops: lessons and challenges in plant genetics. Plant Cell Physiol. 160, 1447-1456. doi: 10. 1093/pcp/pcz079

Connorton, J. M., Balk, J., and Rodríguez-Celma, J. (2017). Iron homeostasis in plants - a brief overview. Metallomics 9, 813-823. doi: 10.1039/C7MT00 $136 \mathrm{C}$

Cress, W. A., Johnson, G. V., and Barton, L. L. (1986). The role of endomycorrhizal fungi in iron uptake by Hilaria jamesii. J. Plant Nutr. 9, 3-7. doi: 10.1080/ 01904168609363465

Cross, A. J., Harnly, J. M., Ferrucci, L. M., Rish, A., Mayne, S. T., and Sinha, R. (2012). Developing a heme iron database for meats a.ccording to meat type, cooking method and doneness level. Food Nutr. Sci. 3, 905-913. doi: 10.4236/ fns.2012.37120

Crowley, D. E. (2006). "Microbial siderophores in the plant rhizosphere," in Iron Nutrition in Plants and Rhizospheric Microorganisms, eds L. L. Barton and J. Abadia (Dordrecht: Springer), 169-198. doi: 10.1007/1-4020-4743-6_8

Crowley, D. E., Reid, C. P., and Szaniszlo, P. J. (1988). Utilization of microbial siderophores in iron acquisition by oat. Plant Physiol. 87, 680-685. doi: 10. 1104/pp.87.3.680

Curie, C., Alonso, J. M., Jean, M. L., Ecker, J. R., and Briat, J. F. (2000). Involvement of NRAMP1 from Arabidopsis thaliana in iron transport. Biochem. J. 347, 749-755. doi: 10.1042/bj3470749
Curie, C., and Briat, J.-F. (2003). Iron transport and signaling in plants. Annu. Rev. Plant Biol. 54, 183-206. doi: 10.1146/annurev.arplant.54.031902.135018

Curie, C., and Mari, S. (2017). New routes for plant iron mining. New Phytol. 214, 521-525. doi: 10.1111/nph.14364

Curie, C., Cassin, G., Couch, D., Divol, F., Higuchi, K., Le Jan, M., et al. (2009). Metal movement within the plant: contribution of nicotianamine and yellow stripe 1-like transporters. Ann. Bot. 103, 1-11. doi: 10.1093/aob/mcn207

Dai, J., Qiu, W., Wang, N., Wang, T., Nakanishi, H., and Zuo, Y. (2019). From Leguminosae/Gramineae intercropping systems to see benefits of intercropping on iron nutrition. Front Plant. Sci. 10:605. doi: 10.3389/fpls.2019.00605

De Santiago, A., García-López, A. M., Quintero, J. M., and Delgado, A. (2013). Effect of Trichoderma asperellum strain T34 and glucose addition on iron nutrition in cucumber grown on calcareous soils. Soil. Biol. Biochem. 57, 598-605. doi: 10.1016/j.soilbio.2012.06.020

De Santiago, A., Perea-Torres, F., Avilés, M., Moreno, M. T., Carmona, E., and Delgado, A. (2019). Shifts in microbial community structure influence the availability of Fe and other micronutrients to lupin (Lupinus albus L.). Appl. Soil Ecol. 144, 42-50. doi: 10.1016/j.apsoil.2019.06.018

De Santiago, A., Quintero, J. M., Avilés, M., and Delgado, A. (2009). Effect of Trichoderma asperellum strain T34 on iron nutrition in white lupin. Soil Biol. Biochem. 41, 2453-2459. doi: 10.1016/j.soilbio.2009.07.033

De Valença, A. W., Bake, A., Brouwer, I. D., and Giller, K. E. (2017). Agronomic biofortification of crops to fight hidden hunger in sub-Saharan Africa. Glob. Food Secur. 12, 8-14. doi: 10.1016/j.gfs.2016.12.001

De Vleesschauwer, D., Cornelis, P., and Höfte, M. (2006). Redox-active pyocyanin secreted by Pseudomonas aeruginosa 7NSK2 triggers systemic resistance to Magnaporthe grisea but enhances Rhizoctonia solani susceptibility in rice. Mol. Plant. Microbe Interact. 19, 1406-1419. doi: 10.1094/MPMI-19- 1406

De Vries, F. T., Griffiths, R. I., Bailey, M., Craig, H., Girlanda, M., Gweon, H. S., et al. (2018). Soil bacterial networks are less stable under drought than fungal networks. Nat. Commun. 9:3033. doi: 10.1038/s41467-018-05516-7

Dehner, C. A., Awaya, J. D., Maurice, P. A., and DuBois, J. L. (2010). Roles of siderophores, oxalate, and ascorbate in mobilization of iron from hematite by the aerobic bacterium Pseudomonas mendocina. Appl. Environ. Microbiol. 76, 2041-2048. doi: 10.1128/AEM.02349-09

Delaporte-Quintana, P., Lovaisa, N. C., Rapisarda, V. A., and Pedrza, R. O. (2020). The plant growth promoting bacteria Gluconacetobacter diazotrophicus and Azospirillum brasilense contribute to the iron nutrition of strawberry plants through siderophores production. Plant. Growth Regul. 91, 185-199. doi: 10. 1007/s10725-020-00598-0

Delimont, N. M., Haub, M. D., and Lindshield, B. L. (2017). The impact of tannin consumption on iron bioavailability and status: a narrative review. Curr. Dev. Nutr. 1, 1-12. doi: 10.3945/cdn.116.000042

Dequiedt, S., Thioulouse, J., Jolivet, C., Saby, N. P. A., Lelievre, M., Maron, P. A., et al. (2009). Biogeographical patterns of soil bacterial communities. Environ. Microbiol. Rep. 1, 251-255. doi: 10.1111/j.1758-2229.2009.00040.x

Dessaux, Y., Grandclément, C., and Faure, D. (2016). Engineering the rhizosphere. Trends Plant. Sci. 21, 266-278. doi: 10.1016/j.tplants.2016.01.002

Dubey, R. K., Tripathi, V., Prabha, R., Chaurasia, R., Singh, D. P., Rao, Ch S, et al. (2020). "Belowground microbial communities: key players for soil and environmental sustainability," in Unravelling the Soil Microbiome. SpringerBriefs in Environmental Science, (Cham: Springer), doi: 10.1007/978-3-030-155 16-2_2

Duchene, O., Vian, J.-F., and Celette, F. (2017). Intercropping with legume for agroecological cropping systems: complementarity and facilitation processes and the importance of soil microorganisms. A review. Agri. Ecosyst. Environ. 240, 148-161. doi: 10.1016/j.agee.2017.02.019

Duijff, B. J., De Kogel, W. J., Bakker, P. A. H. M., and Schippers, B. (1994). Influence of pseudobactin 358 on the iron nutrition of barley. Soil Biol. Biochem. 26, 1681-1688. doi: 10.1016/0038-0717(94)90321-2

Egamberdieva, D., Wirth, S. J., Alqarawi, A. A., Abd-Allah, E., and Hashem, A. (2017). Phytohormones and beneficial microbes: essential components for plants to balance stress and fitness. Front. Microbiol. 8:2104. doi: 10.3389/fmicb. 2017.02104

Fan, M.-S., Zhao, F.-J., Fairweather-Tait, S. J., Poulton, P. R., Dunham, A. J., and MacGrath, S. P. (2008). Evidence of decreasing mineral density in wheat grain over the last 160 years. J. Trace Elem. Med. Bio. 22, 315-324. doi: 10.1016/j. jtemb.2008.07.002 
FAO (2019). Biofortification: A Food-Systems Solution to Help End Hidden Hunger. Rome: FAO. Available online at: http://www.fao.org/3/ca8711en/ca8711en.pdf (accessed June 2, 2021).

FAO (2021). Biofortification: A Food-Systems Solution to Help End Hidden Hunger. Corrigendum. Rome: FAO. Available online at: http://www.fao.org/3/ CA8711EN/Corrigendum-ca8711en.pdf (accessed October 7, 2021).

FAO, IFAD, UNICEF, WFP, and WHO (2019). The State of Food Security and Nutrition in the World 2019. Safeguarding Against Economics Slowdowns and Downturns. Rome: FAO. Available online at: http://www.fao.org/3/ca5162en/ ca5162en.pdf (accessed October 7, 2021).

Farzaneh, M., Vierheilig, H., Lössl, A., and Kaul, H. P. (2011). Arbuscular mycorrhiza enhances nutrient uptake in chickpea. Plant Soil Environ. 57, 465-470. doi: 10.17221/133/2011-PSE

Ferreira, C. M. H., Sousa, C. A., Sanchis-Pérez, I., Lopez-Rayo, S., Barros, M. T., Soares, H. M. V. M., et al. (2019). Calcareous soil interactions of the iron(III) chelates of DPH and Azotochelin and its application on amending iron chlorosis in soybean (Glycine max). Sci. Total Environ. 647, 1586-1593. doi: 10.1016/j.scitotenv.2018.08.069

Ferret, C., Sterckeman, T., Cornu, J.-Y., Gangloff, S., Schalk, I., and Geoffroy, V. A. (2014). Siderophore-promoted dissolution of smectite by fluorescent Pseudomonas. Environ. Microbiol. Rep. 6, 459-467. doi: 10.1111/1758-2229. 12146

Filiz, E., and Kurt, F. (2019). FIT (Fer-like iron deficiency-induced transcription factor) in plant iron homeostasis: genome-wide identification and bioinformatics analyses. J. Plant Biochem. Biotechnol. 28, 143-157. doi: 10.1007/s13562-019-00497-0

Finkelstein, J. L., Fothergill, A., Hackl, L. S., Hass, J. R., and Mehta, S. (2019). Iron biofortification interventions to improve iron status and functional outcomes. Proc. Nutr. Soc. 78, 197-207. doi: 10.1017/S0029665118002847

Finkelstein, J. L., Haas, J. D., and Mehta, S. (2017). Iron-biofortified staple food crops for improving iron status: a review of the current evidence. Curr. Opin. Biotech. 44, 138-145. doi: 10.1016/j.copbio.2017.01.003

Fourcroy, P., Sisó-Terraza, P., Sudre, D., Saviron, M., Reyt, G., Gaymard, F., et al. (2014). Involvement of the ABCG37 transporter in secretion of scopoletin and derivatives by Arabidopsis roots in response to iron deficiency. New Phytol. 201, 155-167. doi: $10.1111 / \mathrm{nph} .12471$

Fourcroy, P., Tissot, N., Gaymard, F., Briat, J.-F., and Dubos, C. (2016). Facilitated Fe nutrition by phenolic compounds excreted by the Arabidopsis ABCG37/PDR9 transporter requires the IRT1/FRO2 high-affinity root Fe2+ transport system. Mol. Plant. 9, 485-488. doi: 10.1016/j.molp.2015.09.010

Freitas, M. A., Medeiros, F. H. V., Carvalho, S. P., Guilherme, L. R. G., Teiseira, W. D., Zhang, H., et al. (2015). Augmenting iron accumulation in cassava by the beneficial soil bacterium Bacillus subtilis (GBO3). Front. Plant Sci. 6:596. doi: $10.3389 /$ fpls.2015.00596

French, E., Kaplan, I., Iyer-Pascuzzi, A., Nakatsu, C. H., and Enders, L. (2021). Emerging strategies for precision microbiome management in diverse agroecosystems. Nat. Plants 7, 256-267. doi: 10.1038/s41477-020-00830-9

Frey, B., Rieder, S. R., Brunner, I., Plotze, M., Koetzsh, S., Lapanje, A., et al. (2010). Weathering-associated bacteria from the Damma glacier forefield: physiological capabilities and impact on granite dissolution. Appl. Environ. Microbiol. 76, 4788-4796. doi: 10.1128/AEM.00657-10

Fustec, J., Lesuffleur, F., Mahieu, S., and Cliquet, J. B. (2010). Nitrogen rhizodeposition of legumes. A review. Agron. Sustain. Dev. 30, 57-66. doi: $10.1051 /$ agro/2009003

Gałązka, A., Grzęda, E., and Jończyk, K. (2019). Changes of microbial diversity in rhizosphere soils of new quality varieties of winter wheat cultivation in organic farming. Sustainability 11:4057. doi: 10.3390/su11154057

Gao, L., Liu, X. M., Du, Y. M., Zong, H., and Shen, G. M. (2019). Effects of tobacco-peanut relay intercropping on soil bacteria community structure. Ann. Microbiol. 69, 1531-1536. doi: 10.1007/s13213-01901537-9

Garcia-Oliveira, A. L., Chander, S., Ortiz, R., Menkir, A., and Gedil, M. (2018). Genetic basis and breeding perspectives of grain iron and zinc enrichment in cereals. Front. Plant Sci. 9:937. doi: 10.3389/fpls.2018.00937

Garnica, M., Bacaicoa, E., Mora, V., San Francisco, S., Baigorri, R., Zamarreño, A. M., et al. (2018). Shoot iron status and auxin are involved in iron deficiencyinduced phytosiderophores release in wheat. BMC Plant Biol. 18:105. doi: $10.1186 /$ s12870-018-1324-3
Ghosh, U. D., Saha, C., Maiti, M., Lahiri, S., Ghosh, S., Seal, A., et al. (2014). Root associated iron oxidizing bacteria increase phosphate nutrition and influence root to shoot partitioning of iron in tolerant plant Typha angustifolia. Plant Soil 381, 279-295. doi: 10.1007/s11104-014-2085-x

Gildersleeve, R. R., and Ocumpaugh, W. R. (1989). Greenhouse evaluation of subterranean clover species for susceptibility to iron-deficiency chlorosis. Crop Sci. 29, 949-951. doi: 10.2135/cropsci1989.0011183X002900040023x

Glasauer, S., Weidler, P. G., Langley, S., and Beveridge, T. J. (2003). Controls on Fe reduction and mineral formation by a subsurface bacterium. Geochim. Cosmochim. Acta. 67, 1277-1288. doi: 10.1016/S0016-7037(02)01199-7

Gnonlonfin, G. J. B., Sanni, A., and Brimer, L. (2012). Review scopoletin - a coumarin phytoalexin with medicinal properties. Crit. Rev. Plant Sci. 31, 47-56. doi: 10.1080/07352689.2011.616039

Gómez-Galera, S., Rojas, E., Sudhakar, D., Zhu, C., Pelacho, A. M., Capelle, T., et al. (2010). Critical evaluation of strategies for mineral fortification of staple food crops. Transgenic Res. 19, 165-180. doi: 10.1007/s11248-009-9311-y

Gonzàlez-Guerrero, M., Escudero, V., Saéz, A., and Tejada-Jimenéz, M. (2016). Transition metal transport in plants and associated endosymbionts: arbuscular mycorrhizal fungi and rhizobia. Front. Plant Sci. 7:1088. doi: 10.3389/fpls.2016. 01088

Gopal, M., and Gupta, A. (2016). Microbiome selection could Spur next-generation plant breeding strategies. Front. Microbiol. 7:1991. doi: 10.3389/fmicb.2016. 01971

Gregory, P. J., Wahbi, A., Adu-Gyamfi, J., Heiling, M., Gruber, M., Joy, E., et al. (2017). Approaches to reduce zinc and iron deficits in food systems. Glob. Food Sec. 15, 1-10. doi: 10.1016/j.gfs.2017.03.003

Grillet, L., and Schmidt, W. (2019). Iron acquisition strategies in land plants: not so different after all. New Phytol. 224:16005. doi: 10.1111/nph.16005

Grillet, L., Mari, S., and Schmidt, W. (2014). Iron in seeds - loading pathways and subcellular localization. Front. Plant Sci. 4:535. doi: 10.3389/fpls.2013.00535

Gu, S., Wei, Z., Shao, Z., Friman, V. P., Cao, K., Yang, T., et al. (2020). Competition for iron drives phytopathogen control by natural rhizosphere microbiomes. Nat Microbiol. 5, 1002-1010. doi: 10.1038/s41564-020-0719-8

Gunes, A., Inal, A., Adak, M. S., Alpaslan, M., Bagci, E. C., Erol, T., et al. (2007). Mineral nutrition of wheat, chickpea and lentil as affected by intecropped cropping and soil moisture. Nutr. Cycl. Agroecosyst. 78, 83-96. doi: 10.1007/ s10705-006-9075-1

Hansen, N. C., Hopkins, B. G., Ellsworth, J. W., and Jolley, V. D. (2006). "Iron nutrition in field crops," in Iron Nutrition in Plants and Rhizospheric Microorganisms, eds L. L. Barton and J. Abadia (Dordrecht: Springer), 23-59. doi: 10.1007/1-4020-4743-6_2

Harbort, C. J., Hashimoto, M., Inoue, H., Niu, Y., Guan, R., Rombolà, A. D., et al. (2020). Root-secreted coumarins and the microbiota interact to improve iron nutrition in Arabidopsis. Cell Host Microbe 28, 825-837.e6. doi: 10.1016/j.chom. 2020.09 .006

Haselwandter, K., Haas, H., Häninger, G., and Winkelmann, G. (2020). Siderophores in plant root tissue: tagetes patula nana colonized by the arbuscular mycorrhizal fungus Gigaspora margarita. Biometals. 33, 137-146. doi: 10.1007/s10534-020-00238-0

Hauggaard-Nielsen, H., Gooding, M., Ambus, P., Corre-Hellou, G., Crozat, Y., Dahlmann, C., et al. (2009). Pea-barley intercropping forefficient symbiotic $\mathrm{N} 2$-fixation, soil $\mathrm{N}$ acquisition and use of other nutrients in European organic cropping systems. Field Crop. Res. 113, 64-71. doi: 10.1016/j.fcr.2009.04.009

Helms, T. C., Scott, R. A., Schapaugh, W. T., Goos, R. J., Franzen, D. W., and Schlegel, A. J. (2010). Soybean iron-deficiency chlorosis tolerance and yield decrease on calcareous soils. Agron. J. 102, 492. doi: 10.2134/agronj2009.0317

Hider, R. C., and Kong, X. (2010). Chemistry and biology of siderophores. Nat. Prod. Rep. 27, 637-657. doi: 10.1039/b906679a

Hinsinger, P., Plassard, C., Tang, C., and Jaillard, B. (2003). Origins of rootmediated $\mathrm{pH}$ changes in the rhizosphere and their responses to environmental constraints: a review. Plant Soil 248, 43-59. doi: 10.1023/A:102237113 0939

Höfte, M., and Bakker, P. A. H. M. (2007). "Competition for iron and induced systemic resistance by siderophores of plant growth promoting rhizobacteria," in Microbial Siderophores, eds A. Varma and S. B. Chincholkar (Berlin: Springer), 121-133. doi: 10.1007/978-3-540-71160-5_6

Horchani, F., Prévot, M., Boscari, A., Evangelisti, E., Meilhoc, E., Bruand, C., et al. (2011). Both plant and bacterial nitrate reductases contribute to nitric oxide 
production in Medicago truncatula nitrogen-fixing nodules. Plant Physiol. 155, 1023-1036. doi: 10.1104/pp.110.166140

Hördt, W., Römheld, V., and Winkelmann, G. (2000). Fusarinines and dimerum acid, mono- and dihydroxamate siderophores from Penicillium chrysogenum, improve iron utilization by strategy I and strategy II plants. Biometals 13, 37-46. doi: 10.1023/a:1009234612486

Housh, A. B., Powell, G., Scott, S., Anstaett, A., Gerheart, A., Benoit, M., et al. (2021). Functional mutants of Azospirillum brasilense elicit beneficial physiological and metabolic responses in Zea mays contributing to increased host iron assimilation. Int. Soc. Microbial. Ecol. J. 15, 1505-1522. doi: 10.1038/ s41396-020-00866- $\mathrm{x}$

Ingraffia, R., Amato, G., Frenda, A. S., and Giambalvo, D. (2019). Impacts of arbuscular mycorrhizal fungi on nutrient uptake, N2 fixation, $\mathrm{N}$ transfer, and growth in a wheat/faba bean intercropping system. PLoS One 14:e0213672. doi: 10.1371/journal.pone.0213672

Ishimaru, Y., Kakei, Y., Shimo, H., Bashir, K., Sato, Y., Sato, Y., et al. (2011). A rice phenolic efflux transporter is essential for solubilizing precipitated apoplasmic iron in the plant stele. J. Biol. Chem. 286, 24649-24655. doi: 10.1074/jbc.M111. 221168

Ishimaru, Y., Suzuki, M., Tsukamoto, T., Suzuki, K., Nakazono, M., Kobayashi, T., et al. (2006). Rice plants take up iron as an Fe3+-phytosiderophore and as Fe2+. Plant J. 45, 335-346. doi: 10.1111/j.1365-313X.2005.02624.x

Jain, A., Singh, A., Chaudhary, A., Singh, S., and Singh, H. B. (2014). Modulation of nutritional and antioxidant potential of seeds and pericarp of pea pods treated with microbial consortium. Food Res. Int. 64, 275-282. doi: 10.1016/j.foodres. 2014.06.033

Jin, C. W., He, Y. F., Tang, C. X., Wu, P., and Zheng, S. J. (2006). Mechanisms of microbially enhanced $\mathrm{Fe}$ acquisition in red clover (Trifolium pratense L.). Plant Cell Environ. 29, 888-897. doi: 10.1111/j.1365-3040.2005.01 468.x

Jin, C. W., Li, G. X., Yu, X. H., and Zheng, S. J. (2010). Plant Fe status affects the composition of siderophore-secreting microbes in the rhizosphere. Ann. Bot. 105, 835-841. doi: 10.1093/aob/mcq071

Jin, C. W., You, G. Y., He, Y. F., Tang, C., Wu, P., and Zheng, S. J. (2007). Iron deficiency-induced secretion of phenolics facilitates the reutilization of root apoplastic iron in red clover. Plant Physiol. 144, 278-285. doi: 10.1104/pp.107. 095794

Jones, P., Garcia, B. J., Furches, A., Tuskan, G. A., and Jacobson, D. (2019). Plant host-associated mechanisms for microbial selection. Front. Plant Sci. 10:862. doi: 10.3389/fpls.2019.00862

Kabir, A. H., Debnath, T., Das, U., Prity, S. A., Haque, H., Rahman, M. M., et al. (2020). Arbuscular mycorrhizal fungi alleviate Fe-deficiency symptoms in sunflower by increasing iron uptake and its availability along with antioxidant defense. Plant Physiol. Biochem. 150, 254-262. doi: 10.1016/j.plaphy.2020.03. 010

Kabir, A. H., Paltridge, N. G., Roessner, U., and Stangoulis, J. C. R. (2013). Mechanisms associated with Fe-deficiency tolerance and signaling in shoots of Pisum sativum. Physiol Plant. 147, 381-395. doi: 10.1111/j.1399-3054.2012. 01682.x

Kaiser, D. E., Lamb, J. A., Bloom, P. R., and Hernandez, J. A. (2014). Comparison of field management strategies for preventing iron deficiency chlorosis in soybean. Agron. J. 106, 1963-1974. doi: 10.2134/agronj13.0296

Kawakami, Y., and Bhullar, N. K. (2018). Molecular processes in iron and zinc homeostasis and their modulation for biofortification in rice. J. Integr. Plant. Biol. 60, 1181-1198. doi: 10.1111/jipb.12751

Kazamia, E., Sutak, R., Paz-Yepes, J., Dorrell, R. G., Roch, F., Mach, H., et al. (2018). Endocytosis-mediated siderophore uptake as a strategy for Fe acquisition in diatoms. Sci. Adv. 4:eaar4536. doi: 10.1126/sciadv.aar 4536

Khan, A., Singh, J., Upadhayay, V. K., Singh, A. V., and Shah, S. (2019). "Microbial biofortification: a green technology through plant growth promoting microorganisms," in Sustainable Green Technologies for Environmental Management, eds S. Shah, V. Venkatramanan, and R. Prasad (Cham: Springer), 255-269. doi: 10.1007/978-981-13-2772-8

Kobae, Y., Tomioka, R., Tanoi, K., Kobayashi, N. I., Ohmori, Y., Nishida, S., et al. (2014). Selective induction of putative iron transporters, OPT8a and OPT8b, in maize by mycorrhizal colonization. Soil Sci. Plant Nutr. 60, 843-847. doi: $10.1080 / 00380768.2014 .949854$
Kobayashi, T., and Nishizawa, N. K. (2012). Iron uptake, translocation, and regulation in higher plants. Annu. Rev. Plant Biol. 63, 131-152. doi: 10.1146/ annurev-arplant-042811-105522

Kobayashi, T., Nozoye, T., and Nishizawa, N. K. (2019). Iron transport and its regulation in plants. Free Radical Bio. Med. 133, 11-20. doi: 10.1016/j. freeradbiomed.2018.10.439

Kocak, K. (2014). Evaluation of Iron Deficiency Chlorosis in Soybeans (Glycine max). ETD Collection for University of Nebraska - Lincoln. 24. Available online at: https://digitalcommons.unl.edu/dissertations/AAI3618676/ (accessed June 23, 2021).

Kraemer, S. M. (2004). Iron oxide dissolution and solubility in the presence of siderophores. Aquat. Sci. 66, 3-18. doi: 10.1007/s00027-003-0690-5

Kuiper, I., Bloemberg, G. V., Noreen, S., Thomas-Oates, J., and Lugtengerg, B. (2001). Increased uptake of putrescine in the rhizosphere inhibits competitive root colonization by Pseudomonas fluorescens strain WCS365. Mol. Plant. Microbe Interact. 14, 1096-1104. doi: 10.1094/MPMI.2001.14.9.1096

Kumar, A., Kaur, G., Goel, P., Bhati, K. K., Kaur, M., Shukla, V., et al. (2019). Genome-wide analysis of oligopeptide transporters and detailed characterization of yellow stripe transporter genes in hexaploid wheat. Funct. Integr. Genomics. 19, 75-90. doi: 10.1007/s10142-018-0629-5

Kuypers, M. M., Marchant, A. K., and Kartal, B. (2018). The microbial nitrogencycling network. Nat. Rev. Microbiol. 16, 263-276. doi: 10.1038/nrmicro. 2018.9

Labidi, S., Ben Jeddi, F., Tisserant, B., Debiane, D., Rezgui, S., GrandmouginFerjani, A., et al. (2012). Role of arbuscular mycorrhizal symbiosis in root mineral uptake under CaCO3 stress. Mycorrhiza. 22, 337-345. doi: 10.1007/ s00572-011-0405-z

Lasa, A. V., Mašínová, T., Baldrian, P., and Fernández-López, M. (2019). Bacteria from the endosphere and rhizosphere of Quercus spp. use mainly cell wallassociated enzymes to decompose organic matter. PLoS One 14:e0214422. doi: 10.1371/journal.pone.0214422

Lassoued, R., Smyth, S. J., Phillips, P. W. B., and Hesseln, H. (2018). Regulatory uncertainty around new breeding techniques. Front. Plant Sci. 9:1291. doi: 10.3389/fpls.2018.01291

Lavania, M., Chauhan, P. S., Chauhan, S. V. S., Singh, H. B., and Nautiyal, C. S. (2006). Induction of plant defense enzymes and phenolics by treatment with plant growth-promoting rhizobacteria Serratia marcescens NBRI1213. Curr. Microbiol. 52, 363-368. doi: 10.1007/s00284-005-5578-2

Leake, J. R., Shaw, G., and Read, D. J. (1990). The biology of mycorrhiza in the Ericaceae. XVI. Mycorrhiza and iron uptake in Calluna vulgaris (L.) Hull in the presence of two calcium salts. New Phythol. 114, 651-657. doi: 10.1111/j.14698137.1990.tb00436.x

Lei, G. J., Zhu, X. F., Wang, Z. W., Dong, F., Dong, N. Y., and Zheng, S. J. (2014). Abscisic acid alleviates iron deficiency by promoting root iron reutilization and transport from root to shoot in Arabidopsis. Plant Cell Environ. 37, 852-863. doi: $10.1111 /$ pce. 12203

Lemanceau, P., Barret, M., Mazurier, S., Mondy, S., Pivato, B., Fort, T., et al. (2017a). Chapter Five - Plant communication with associated microbiota in the spermosphere, rhizosphere and phyllosphere. Adv. Bot. Res. 8, 101-133. doi: 10.1016/bs.abr.2016.10.007

Lemanceau, P., Bauer, P., Kraemer, S., and Briat, J.-F. (2009). Iron dynamics in the rhizosphere as a case study for analyzing interactions between soils, plants and microbes. Plant Soil. 321, 513-535. doi: 10.1007/s11104-009-0039-5

Lemanceau, P., Blouin, M., Muller, D., and Moënne-Loccoz, Y. (2017b). Let the core microbiota be functional. Trends Plant Sci. 22, 583-595. doi: 10.1016/j. tplants.2017.04.008

Leyval, C., and Reid, C. P. P. (1991). Utilization of microbial siderophores by mycorrhizal and non-mycorrhizal pine roots. New Phytol. 119, 93-98. doi: 10.1111/j.1469-8137.1991.tb01011.x

Li, G., Xu, W., Kronzucker, H. J., and Shi, W. (2015). Ethylene is critical to the maintenance of primary root growth and Fe homeostasis under Fe stress in Arabidopsis. J. Exp. Bot. 66, 2041-2054. doi: 10.1093/jxb/erv005

Li, Q., Chen, J., Wu, L., Luo, X., and Li, N. (2018). Belowground interactions impact the soil bacterial community, soil fertility, and crop yield in maize/peanut intercropping systems. Int. J. Mol. Sci. 19:622. doi: 10.3390/ijms19020622

Li, Q., Yang, A., and Zhang, W.-H. (2016). Efficient acquisition of iron confers greater tolerance to saline-alkaline stress in rice (Oryza sativa L.). J. Exp. Bot. 67, 6431-6444. doi: 10.1093/jxb/erw407 
Liu, A., Hamel, C., Hamilton, R. I., Ma, B. L., and Smith, D. L. (2000). Acquisition of $\mathrm{Cu} . \mathrm{Zn}, \mathrm{Mn}$ and Fe by mycorrhizal maize (Zea mays L.) grown in soil at different $\mathrm{P}$ and micronutrient levels. Mycorrhiza 9, 331-336. doi: 10.1007/ s005720050277

Liu, Y., Yang, H., Liu, Q., Zhao, X., Xie, S., Wang, Z., et al. (2021). Effect of two different sugarcane cultivars on rhizosphere bacterial communities of sugarcane and soybean upon intercropping. Front. Microbiol. 11:596472. doi: 10.3389/ fmicb.2020.596472

Liu, Z., Beskrovnaya, P., Melnyk, R. A., Hossain, S. S., Khorasani, S., O’Sullivan, L. R., et al. (2018). A genome-wide screen identifies genes in rhizosphereassociated Pseudomonas required to evade plant defenses. mBio 9, e00433-18. doi: $10.1128 / \mathrm{mBio} .00433-18$

Lockyer, S., White, A., and Buttriss, J. L. (2018). Biofortified crops for tackling micronutrient deficiencies - what impact are these having in developing countries and could they be of relevance within Europe? Nutr. Bull. 43, 319-357. doi: $10.1111 /$ nbu. 12347

Longnecker, N., and Welch, R. M. (1990). Accumulation of apoplastic iron in plant roots: a factor in the resistance of soybeans to iron-deficiency induced chlorosis? Plant Physiol. 92, 17-22. doi: 10.1104/pp.92.1.17

Lurthy, T., Cantat, C., Jeudy, C., Declerck, P., Gallardo, K., Barraud, C., et al. (2020). Impact of bacterial siderophores on iron status and ionome in pea. Front. Plant Sci. 11:730. doi: 10.3389/fpls.2020.00730

Mahmoudi, H., Koyro, H.-W., Debez, A., and Abdelly, C. (2009). Comparison of two chickpea varieties regarding their responses to direct and induced Fe deficiency. Environ. Exp. Bot. 66, 349-356. doi: 10.1016/j.envexpbot.2009.03. 013

Malhotra, H., Pandey, R., Sharma, S., and Bindraban, P. S. (2019). Foliar fertilization: possible routes of iron transport from leaf surface to cell organelles. Arch. Agron. Soil Sci. 66, 279-300. doi: 10.1080/03650340.2019.1616288

Manthey, J. A., Tisserat, B., and Crowley, D. E. (1996). Root responses of sterilegrown onion plants to iron deficiency. J. Plant. Nutr. 19, 145-161. doi: 10.1080/ 01904169609365113

Manwaring, H. R., Bligh, H. F. J., and Yadav, R. (2016). The challenges and opportunities associated with biofortification of pearl millet (Pennisetum glaucum) with elevated levels of grain iron and zinc. Front. Plant Sci. 7:1944. doi: $10.3389 /$ fpls.2016.01944

Marschner, H. (1995). Mineral Nutrition of Higher Plants, 2nd Edn. London: Academic Press, 889.

Marschner, P., Crowley, D., and Rengel, Z. (2011). Rhizosphere interactions between microorganisms and plants govern iron and phosphorus acquisition along the root axis - model and research methods. Soil Biol. Biochem. 43, 883-894. doi: 10.1016/j.soilbio.2011.01.005

Mary, V., Ramos, M. S., Gillet, C., Socha, A., Giraudat, J., Agorio, A., et al. (2015). Bypassing iron storage in endodermal vacuoles rescues the iron mobilization defect in the natural resistance associated-macrophage protein3natural resistance associated-macrophage protein4 Double Mutant. Plant Physiol. 169, 748-759. doi: 10.1104/pp.15.00380

Masalha, J., Kosegarten, H., Elmaci, Ö, and Mengel, K. (2000). The central role of microbial activity for iron acquisition in maize and sunflower. Biol. Fertil. Soils 30, 433-439. doi: 10.1007/s003740050021

Michel, L., Beyá-Marshall, V., Rombolà, A. D., Pastenes, C., and Covarrubias, J. I. (2019). Evaluation of FE-heme applications or intercropping for preventing iron deficiency in blueberry. J. Soil Sci. Plant. Nutr. 19, 117-126. doi: 10.1007/ s42729-019-0017-9

Mishra, P. K., Bisht, S. C., Ruwari, P., Joshi, G. P., Singh, G., Bisht, J. T., et al. (2011). Bioassociative effect of cold tolerant Pseudomonas spp. and Rhizobium leguminosarum-PR1 on iron acquisition, nutrient uptake and growth of lentil (Lens culinaris L.). Eur. J. Soil Biol. 47, 35-43. doi: 10.1016/j.ejsobi.2010. 11.005

Morrissey, J., Baxter, I. R., Lee, J., Li, L., Lahner, B., Grotz, N., et al. (2009). The ferroportin metal efflux proteins function in iron and cobalt homeostasis in Arabidopsis. Plant Cell. 21, 3326-3338. doi: 10.1105/tpc.109.069401

Murgia, I., Arosio, P., Tarantino, D., and Soave, C. (2012). Biofortification for combating 'hidden hunger' for iron. Trends Plant Sci. 17, 47-55. doi: 10.1016/ j.tplants.2011.10.003

Mushtaq, Z., Asghar, H. N., Zahir, Z. A., and Massood, M. (2021). The interactive approach of rhizobacteria and L-tryptophan on growth, physiology, tuber characteristics, and iron concentration of potato (Solanum tuberosum L.). J. Plant Growth Regul. doi: 10.1007/s00344-021-10395-2

Nagata, T. (2017). Effect of Pseudomonas fluorescens inoculation on the improvement of iron deficiency in tomato. Plant Root. 11, 1-9. doi: 10.3117/ plantroot.11.1

Nagata, T., Oobo, T., and Aozasa, O. (2013). Efficacy of a bacterial siderophore, pyoverdine, to supply iron to Solanum lycopersicum plants. J. Biosci. Bioengi. 115, 686-690. doi: 10.1016/j.jbiosc.2012.12.018

Neumann, A., Schmidtke, K., and Rauber, R. (2007). Effects of crop density and tillage system on grain yield and $\mathrm{N}$ uptake from soil and atmosphere of sole and intercropped pea and oat. Field Crop. Res. 100, 285-293. doi: 10.1016/j.fcr.2006. 08.001

Nevo, Y., and Nelson, N. (2006). The NRAMP family of metal-ion transporters. Biochim. Biophys. Acta - Mol. Cell Res. 1763, 609-620. doi: 10.1016/j.bbamcr. 2006.05.007

Norton, J., and Ouyang, Y. (2019). Controls and adaptive management of nitrification in agricultural soils. Front. Microbiol. 10:1931. doi: 10.3389/fmicb. 2019.01931

Orera, I., Abadía, A., Abadía, J., and Álvarez-Fernández, A. (2009). Determination of o,oEDDHA - a xenobiotic chelating agent used in Fe fertilizers - in plant tissues by liquid chromatography/electrospray mass spectrometry: overcoming matrix effects. Rapid Commun. Mass Spectro. 23, 1694-1702. doi: 10.1002/rcm. 4056

Orera, I., Rodríguez-Castrillón, J. A., Moldovan, M., García-Alonso, J. I., Abadía, A., Abadía, J., et al. (2010). Using a dual-stable isotope tracer method to study the uptake, xylem transport and distribution of $\mathrm{Fe}$ and its chelating agent from stereoisomers of an Fe(iii)-chelate used as fertilizer in Fe-deficient Strategy I plants. Metallomics 2, 646-657. doi: 10.1039/C0MT00018C

Palmer, C. M., Hindt, M. N., Schmidt, H., Clemens, S., and Guerinot, M. L. (2013). MYB10 and MYB72 are required for growth under iron-limiting conditions. PLoS Genet. 9:e1003953. doi: 10.1371/journal.pgen.1003953

Pedas, P., Ytting, C. K., Fuglsang, A. T., Jahn, T. P., Schjoerring, J. K., and Husted, S. (2008). Manganese efficiency in barley: identification and characterization of the metal ion transporter HvIRT1. Plant Physiol. 148, 455-466. doi: 10.1104/ pp. 108.118851

Pieterse, C. M. J., Zamioudis, C., Berendsen, R. L., Weller, D., Van Wees, S. C. M., and Bakker, P. A. (2014). Induced systemic resistance by beneficial microbes. Annu. Rev. Phytopathol. 52, 347-375. doi: 10.1146/annurev-phyto-082712102340

Pivato, B., Semblat, A., Guégan, T., Jacquiod, S., Martin, J., Deau, F., et al. (2021). Rhizosphere bacterial networks, but not diversity, are impacted by pea-wheat intecropping. Front. Microbiol. 12:674556. doi: 10.3389/fmicb.2021.674556

Pourbabaee, A. A., Shoaibi, F., Emami, S., and Alikhani, H. A. (2018). The potential contribution of siderophore producing bacteria on growth and Fe ion concentration of sunflower (Helianthus annuus L.) under water stress. J. Plant Nutr. 41, 619-626. doi: 10.1080/01904167.2017.1406112

Prity, S. A., Sajib, S. A., Rahman, M. M., Haider, S. A., and Kabir, A. H. (2020). Arbuscular mycorrhizal fungi mitigate Fe deficiency symptoms in sorghum through phytosiderophore-mediated Fe mobilization and restoration of redox status. Protoplasma 257, 1373-1385. doi: 10.1007/s00709-020-01517-w

Qiao, Y. J., Li, Z. H., Wang, X., Zhu, B., Hu, Y. G., and Zeng, Z. H. (2012). Effect of legume-cereal mixtures on the diversity of bacterial communities in the rhizosphere. Plant. Soil Environ. 58, 174-180. doi: 10.17221/351/2011-PSE

Radzki, W., Gutierrez Mañero, F. J., Algar, E., Lucas Garcia, J. A., Garcia-Villaraco, A., and Ramos Solano, B. (2013). Bacterial siderophores efficiently provide iron to iron-starved tomato plants in hydroponics culture. Antonie Leeuwenhoek 104, 321-330. doi: 10.1007/s10482-013-9954-9

Rahman, M. A., Parvin, M., Das, U., Ela, E. J., Lee, S. H., Lee, K. W., et al. (2020). Arbuscular mycorrhizal symbiosis mitigates iron $(\mathrm{Fe})$-deficiency retardation in alfalfa (Medicago sativa L.) through the enhancement of Fe accumulation and sulfur-assisted antioxidant defense. Int. J. Mol. Sci. 21:2219. doi: 10.3390/ ijms21062219

Rajkumar, M., Ae, N., Prasad, M. N. V., and Freitas, H. (2010). Potential of siderophore-producing bacteria for improving heavy metal phytoextraction. Trends Biotechnol. 28, 142-149. doi: 10.1016/j.tibtech.2009.12.002

Ranjard, L., Dequiedt, S., Chemidlin Prévost-Bouré, N., Thioulouse, J., Saby, N. P. A., Lelievre, M., et al. (2013). Turnover of soil bacterial diversity driven by 
wide-scale environmental heterogeneity. Nat. Commun. 4:1434. doi: 10.1038/ ncomms 2431

Ravanbakhsh, M., Sasidharan, R., Voesenek, L. A. C. J., Kowalchuk, G. A., and Jousset, A. (2018). Microbial modulation of plant ethylene signaling: ecological and evolutionary consequences. Microbiome 6:52. doi: 10.1186/s40168-0180436- 1

Reza, M. (2017). Assessing the Effect of Siderophore Producing Bacteria for the Iron Nutrition in Lentil and Pea. Ph.D. thesis. Saskatchewan, SK: University of Saskatchewan, 130.

Rijavec, T., and Lapanje, A. (2016). Hydrogen cyanide in the rhizosphere: not suppressing plant pathogens, but rather regulating availability of phosphate. Front. Microbiol. 7:1785. doi: 10.3389/fmicb.2016.01785

Robin, A., Mazurier, S., Mougel, C., Vansuyt, G., Corberand, T., Meyer, J.-M., et al. (2007). Diversity of root-associated fluorescent pseudomonads as affected by ferritin overexpression in tobacco: diversity of fluorescent pseudomonads in rhizosphere. Environ. Microbiol. 9, 1724-1737. doi: 10.1111/j.1462-2920.2007. 01290.x

Robin, A., Mougel, C., Siblot, S., Vansuyt, G., Mazurier, S., and Lemanceau, P. (2006). Effect of ferritin overexpression in tobacco on the structure of bacterial and pseudomonad communities associated with the roots: structure of rhizosphere bacterial and pseudomonad communities. FEMS Microbiol. Ecol. 58, 492-502. doi: 10.1111/j.1574-6941.2006.00174.x

Robin, A., Vansuyt, G., Hinsinger, P., Meyer, J.-M., Briat, J.-F., and Lemanceau, P. (2008). Chapter 4 Iron dynamics in the rhizosphere. Adv. Agron. 99, 183-225. doi: 10.1016/S0065-2113(08)00404-5

Rodriguez, P. A., Rothballer, M., Chowdhury, S. P., Nussbaumer, T., Gutjahr, C., and Falter-Braun, P. (2019). Systems biology of plant-microbiome interactions. Mol. Plant 12, 804-821. doi: 10.1016/j.molp.2019.05.006

Rodríguez-Celma, J., Lin, W. D., Fu, G. M., Abadía, J., López-Millán, A. F., and Schmidt, W. (2013). Mutually exclusive alterations in secondary metabolism are critical for the uptake of insoluble iron compounds by Arabidopsis and Medicago truncatula. Plant Physiol. 162, 1473-1485. doi: 10.1104/pp.113. 220426

Romera, F. J., García, M. J., Lucena, C., Martínez-Medina, A., Aparicio, M. A., Ramos, J., et al. (2019). Induced systemic resistance (ISR) and Fe deficiency responses in dicot plants. Front. Plant Sci. 10:287. doi: 10.3389/fpls.2019. 00287

Roschzttardtz, H., Conéjéro, G., Curie, C., and Mari, S. (2009). Identification of the endodermal vacuole as the iron storage compartment in the Arabidopsis Embryo. Plant Physiol. 151, 1329-1338. doi: 10.1104/pp.109. 144444

Rroço, E., Kosegarten, H., Harizaj, F., Imani, J., and Mengel, K. (2003). The importance of soil microbial activity for the supply of iron to sorghum and rape. Eur. J. Agron. 19, 487-493. doi: 10.1016/S1161-0301(02)00185-5

Sadrarhami, A., Grove, J. H., and Zeinali, H. (2021). The microbial siderophore desferrioxamine B inhibits Fe and $\mathrm{Zn}$ uptake in three spring wheat genotypes grown in Fe-deficient nutrient solution. J. Plant Nut. 44, 2299-2309. doi: 10.1080/01904167.2021.1899205.

Saha, M., Sarkar, S., Sarkar, B., Sharma, B. K., Bhattacharjee, S., and Tribedi, P. (2016). Microbial siderophores and their potential applications: a review. Environ. Sci. Pollut. Res. 23, 3984-3999. doi: 10.1007/s11356-015-4294-0

Sandberg, A.-S. (2002). Bioavailability of minerals in legumes. Br. J. Nutr. 88, 281-285. doi: 10.1079/BJN/2002718

Schmid, N. B., Giehl, R. F. H., Döll, S., Mock, H. P., Strehmel, N., Scheel, D., et al. (2014). Feruloyl-CoA 6'-Hydroxylase1-dependent coumarins mediate iron acquisition from alkaline substrates in Arabidopsis. Plant Physiol. 164, 160-172. doi: 10.1104/pp.113.228544

Schmidt, H., Günther, C., Weber, M., Sporlein, C., Losher, S., Böttcher, C., et al. (2014). Metabolome analysis of Arabidopsis thaliana roots identifies a key ketabolic pathway for iron acquisition. PLoS One 9:e102444. doi: 10.1371/ journal.pone.0102444

Sessitsch, A., Hardoim, P., Döring, J., Weilharter, A., Krause, A., Woyke, T. M., et al. (2012). Functional characteristics of an endophyte community colonizing rice roots as revealed by metagenomic analysis. Mol. Plant Microbe. Interact. 25, 28-36. doi: 10.1094/MPMI-08-11-0204

Sharma, A., Shankhdhar, D., and Shankhdhar, S. C. (2013). Enhancing grain iron content of rice by the application of plant growth promoting rhizobacteria. Plant Soil Environ. 59, 89-94. doi: 10.17221/683/2012-PSE
Sharma, S. B., Sayyed, R. Z., Trivedi, M. H., and Gobi, T. A. (2013). Phosphate solubilizing microbes: sustainable approach for managing phosphorus deficiency in agricultural soils. SpringerPlus. 2:587. doi: 10.1186/2193-1801-2587

Shenker, M., Chen, Y., Ghirlando, R., Oliver, I., Helmann, M., and Hadar, Y. (1995). Chemical structure and biological activity of a siderophore produced by Rhizopus arrhizus. Soil Sci. Soc. Am. J. 59, 837. doi: 10.2136/sssaj1995. 03615995005900030029x

Shi, R., Melzer, M., Zheng, S., Benke, A., Stich, B., and von Wiren, N. (2018). Iron retention in root hemicelluloses causes genotypic variability in the tolerance to iron deficiency-induced chlorosis in maize. Front. Plant Sci. 9:557. doi: 10.3389/fpls.2018.00557

Shirley, M., Avoscan, L., Bernaud, E., Vansuyt, G., and Lemanceau, P. (2011). Comparison of iron acquisition from $\mathrm{Fe}$-pyoverdine by strategy I and strategy II plants. Botany. 89, 731-735. doi: 10.1139/b11-054

Shomer, I., Novacky, A. J., Pike, S. M., Yermiyahu, U., and Kinraide, T. B. (2003). Electrical potentials of plant cell walls in response to the ionic environment. Plant Physiol. 133, 411-422. doi: 10.1104/pp.103.024539

Singh, A., Jain, A., Sarma, B. K., Upadhyray, R. S., and Signh, H. B. (2014). Rhizosphere competent microbial consortium mediates rapid changes in phenolic profiles in chickpea during Sclerotium rolfsii infection. Microbiol. Res. 169, 353-360. doi: 10.1016/j.micres.2013.09.014

Singh, D., and Prasanna, R. (2020). Potential of microbes in the biofortification of $\mathrm{Zn}$ and Fe in dietary food grains. A review Agron. Sustain. Devl. 40:15. doi: 10.1007/s13593-020-00619-2

Singh, D., Geat, N., Rajawat, M. V. S., Mahajan, M. M., and Prasanna, R. (2017). Deciphering the mechanisms of endophyte-mediated biofortification of Fe and Zn in wheat. J. Plant Growth Regul. 37, 174-182. doi: 10.1007/s00344-0179716-4

Singh, D., Geat, N., Rajawat, M. V. S., Prasanna, M. V., Kar, A., Singh, A. M., et al. (2018). Prospecting endophytes from different Fe or $\mathrm{Zn}$ accumulating wheat genotypes for their influence as inoculants on plant growth, yield, and micronutrient content. Ann. Microbiol. 68, 815-833. doi: 10.1007/s13213-0181388-1

Sisó-Terraza, P., Rios, J. J., Abadía, J., Abadía, A., and Álvarez-Fernández, A. (2016). Flavins secreted by roots of iron-deficient Beta vulgaris enable mining of ferric oxide via reductive mechanisms. New Phytol. 209, 733-745. doi: 10.1111/nph.13633

Slamet-Loedin, I. H., Johnson-Beebout, S. E., Impa, S., and Tsakirpaloglou, N. (2015). Enriching rice with $\mathrm{Zn}$ and Fe while minimizing Cd risk. Front. Plant Sci. 6:121. doi: 10.3389/fpls.2015.00121

Smith, S. E., Jakobsen, I., Grønlund, M., and Smith, F. A. (2011). Roles of arbuscular mycorrhizas in plant phosphorus nutrition: interactions between pathways of phosphorus uptake in arbuscular mycorrhizal roots have important implications for understanding and manipulating plant phosphorus acquisition. Plant Physiol. 156, 1050-1057. doi: 10.1104/pp.111.174581

Soares, E. V., and Soares, H. M. V. M. (2021). Harmful effects of metal(loid) oxide nanoparticles. Appl. Microbiol. Biotechnol. 105, 1379-1394. doi: 10.1007/ s00253-021-11124-1

Song, C., Mazzola, M., Cheng, X., Oetjen, J., Alexandrov, T., Dorrestein, P., et al. (2015). Molecular and chemical dialogues in bacteria-protozoa interactions. Sci. Rep. 5, 12837. doi: 10.1038/srep12837

Spehn, E. M., Joshi, J., Schmid, B., Alphei, J., and Körner, C. (2000). Plant diversity effects on soil heterotrophic activity in experimental grassland ecosystems. Plant Soil 224, 217-230. doi: 10.1023/A:1004891807664

Stringlis, I. A., Yu, K., Feussner, K., de Jonge, R., Van Bentum, S., Van Verk, M. C., et al. (2018). MYB72-dependent coumarin exudation shapes root microbiome assembly to promote plant health. Proc. Natl. Acad. Sci. U.S.A. 115, E5213E5222. doi: 10.1073/pnas.1722335115

Su, H., Chu, Y., Bai, J., Gong, L., Huang, J., Xu, W., et al. (2018). Genome-wide identification and comparative analysis for OPT Family genes in Panax ginseng and eleven flowering plants. Molecules. 24, 15. doi: 10.3390/molecules 24010015

Sullivan, T. S., and Gadd, G. M. (2019). Chapter Three - Metal bioavailability and the soil microbiome. Adv. Agron. 155, 79-120. doi: 10.1016/bs.agron.2019.01. 004

Sun, Y. M., Zhang, N. N., Wang, E. T., Yuan, H. L., Yang, J. S., and Chen, W. X. (2009). Influence of intercropping and intercropping plus rhizobial inoculation on microbial activity and community composition in rhizosphere of alfalfa 
(Medicago sativa L.) and Siberian wild rye (Elymus sibiricus L.). FEMS Microbiol. Ecol. 70, 218-226. doi: 10.1111/j.1574-6941.2009.00752.x

Taschen, E., Amenc, L., Tournier, E., Deleporte, P., Malagoli, P., Fustec, J., et al. (2017). Cereal-legume intercropping modifies the dynamics of the active rhizospheric bacterial community. Rhizosphere 3, 191-195. doi: 10.1016/j. rhisph.2017.04.011

Theis, K. R., Dheilly, N. M., Klassen, J. L., Brucker, R. M., and Baines, J. F. (2016). Getting the hologenome concept right: an eco-evolutionary framework for hosts and their microbiomes. mSystems 1, e00028-16. doi: 10.1128/mSystems. 00028-16

Trapet, P., Avoscan, L., Klinguer, A., Pateyron, S., Citerne, S., Chervin, C., et al. (2016). The Pseudomonas fluorescens siderophore pyoverdine weakens Arabidopsis thaliana defense in favor of growth in irondeficient conditions. Plant Physiol. 171, 675-693. doi: 10.1104/pp.15. 01537

Tsai, H.-H., and Schmidt, W. (2017). One way. Or another? Iron uptake in plants. New Phytol. 214, 500-505. doi: 10.1111/nph.14477

Turner, T. R., Ramakrishnan, K., Walshaw, J., Heavens, D., Alston, M., Swarbreck, D., et al. (2013). Comparative metatranscriptomics reveals kingdom level changes in the rhizosphere microbiome of plants. Int. Soc. Microbial. Ecol. J. 7, 2248-2258. doi: 10.1038/ismej.2013.119

UNDP (2015). Sustainable Development Goals. In: United Nations Development Programme. New York, NY: UNDP. Available online at: https://www.undp.org/content/undp/en/home/sustainable-developmentgoals.html (accessed July 2, 2021).

Van Loon, L. C., Bakker, P. A., van der Heijdt, W. H., Wendehenne, D., and Pugin, A. (2008). Early responses of tobacco suspension cells to rhizobacterial elicitors of induced systemic resistance. Mol. Plant Microbe Interact. 21, 1609-1621. doi: 10.1094/MPMI-21-12-1609

Vandenkoornhuyse, P., Quaiser, A., Duhamel, M., Van, A. L., and Dufresne, A. (2015). The importance of the microbiome of the plant holobiont. New Phytol. 206, 1196-1206. doi: 10.1111/nph.13312

Vansuyt, G., Robin, A., Briat, J.-F., Curie, C., and Lemanceau, P. (2007). Iron acquisition from Fe-pyoverdine by Arabidopsis thaliana. Mol. Plant Microbe Interact. 20, 441-447. doi: 10.1094/MPMI-20-4-0441

Vansuyt, G., Souche, G., Straczek, A., Briat, J.-F., and Jaillard, B. (2003). Flux of protons released by wild type and ferritin over-expressor tobacco plants: effect of phosphorus and iron nutrition. Plant Physiol. Biochem. 41, 27-33. doi: 10.1016/S0981-9428(02)00005-0

Vasconcelos, M., Eckert, H., Arahana, V., Graef, G., Grusak, M. A., and Clemente, T. (2006). Molecular and phenotypic characterization of transgenic soybean expressing the Arabidopsis ferric chelate reductase gene. FRO2. Planta. 224, 1116-1128. doi: 10.1007/s00425-006-0293-1

Vert, G., Barberon, M., Zelazny, E., Séguéla, M., Briat, J.-F., and Curie, C. (2009). Arabidopsis IRT2 cooperates with the high-affinity iron uptake system to maintain iron homeostasis in root epidermal cells. Planta 229, 1171-1179. doi: 10.1007/s00425-009-0904-8

Vora, S. M., Ankati, S., Patole, C., Podile, A. R., and Archana, G. (2021). Alterations of primary metabolites in root exudates of intecropped Cajanus cajan-Zea mays modulate the adaptation and proteome of Ensifer (Sinorhizobium) fredii NGR234. Microb. Ecol. doi: 10.1007/s00248-021-01818-4. [Epub ahead of print].

Wahbi, S., Maghraoui, T., Hafidi, M., Sanguin, H., Oufdou, K., Prin, Y., et al. (2016a). Enhanced transfer of biologically fixed $\mathrm{N}$ from faba bean to intercropped wheat through mycorrhizal symbiosis. Appl. Soil Ecol. 107, 91-98. doi: 10.1016/j.apsoil.2016.05.008

Wahbi, S., Prin, Y., Thioulouse, J., Sanguin, H., Baudoin, E., Maghraoui, T., et al. (2016b). Impact of wheat/faba bean mixed cropping or rotation systems on soil microbial functionalities. Front. Plant Sci. 7:1364. doi: 10.3389/fpls.2016. 01364

Wakeel, A., Farooq, M., Bashir, K., and Ozturk, L. (2018). "Micronutrient malnutrition and biofortification: recent advances and future perspectives," in Plant Micronutrient Use Efficiency, eds M. A. Houssain, T. Kamiya, L. S. Phan Tran, and T. Fujiwara (Amsterdam: Elsevier), 225-243. doi: 10.1016/B978-012-812104-7.00017-4

Wang, J., Zhou, C., Xiao, X., Xie, Y., Zhu, L., and Ma, Z. (2017). Enhanced iron and selenium uptake in plants by volatile emissions of Bacillus amyloliquefaciens (BF06). Appl. Sci. 7, 85. doi: 10.3390/app7010085
Wang, Y., Brown, H. N., Crowley, D. E., and Szaniszlo, P. J. (1993). Evidence for direct utilization of a siderophore, ferrioxamine $\mathrm{B}$, in axenically grown cucumber. Plant Cell Environ. 16, 579-585. doi: 10.1111/j.1365-3040.1993. tb00906.x

Waters, B. M., Amundsen, K., and Graef, G. (2018). Gene expression profiling of iron deficiency chlorosis sensitive and tolerant soybean indicates key roles for phenylpropanoids under alkalinity stress. Front. Plant Sci. 9:10. doi: 10.3389/ fpls.2018.00010

Waters, B. M., and Sankaran, R. P. (2011). Moving micronutrients from the soil to the seeds: genes and physiological processes from a biofortification perspective. Plant Sci. 180, 562-574. doi: 10.1016/j.plantsci.2010.12.003

Wei, Z., and Jousset, A. (2017). Plant breeding goes microbial. Trends Plant Sci. 22, 555-558. doi: 10.1016/j.tplants.2017.05.009

Welch, R. M., House, W. A., Beebe, S., and Cheng, Z. (2000). Genetic selection for enhanced bioavailable levels of iron in bean (Phaseolus vulgaris L.) seeds. J. Agr. Food Chem. 48, 3576-3580. doi: 10.1021/jf0000981

Werra, P., de, Péchy-Tarr, M., Keel, C., and Maurhofer, M. (2009). Role of gluconic acid production in the regulation of biocontrol traits of Pseudomonas fluorescens CHA0. Appl. Environ. Microbiol. 75, 4162-4174. doi: 10.1128/AEM. 00295-09

Wezel, A., Casagrande, M., Celette, F., Vian, J. F., Ferrer, A., and Peigné, J. (2014). Agroecological practices for sustainable agriculture. A review. Agron. Sustain. Dev. 34, 1-20. doi: 10.1007/s13593-013-0180-7

White, P. J., and Broadley, M. R. (2009). Biofortification of crops with seven mineral elements often lacking in human diets - iron, zinc, copper, calcium, magnesium, selenium and iodine: research review. New Phytol. 182, 49-84. doi: $10.1111 / j .1469-8137.2008 .02738 . x$

White, P., and Broadley, M. (2005). Biofortifying crops with essential mineral elements. Trends Plant Sci. 10, 586-593. doi: 10.1016/j.tplants.2005.10.001

Wille, L., Messmer, M. M., Studer, B., and Hohmann, P. (2019). Insights to plantmicrobe interactions provide opportunities to improve resistance breeding against root diseases in grain legumes. Plant Cell Environ. 42, 20-40. doi: 10.1111 /pce. 13214

Winkelmann, G. (2017). A search for glomuferrin; a potential siderophore of arbuscular fungi of the genus Glomus. Biometals 30, 559-564. doi: 10.1007/ s10534-017-0026-x

Winterbourn, C. C. (1995). Toxicity of iron and hydrogen peroxide: the Fenton reaction. Toxicol. Lett. 8, 969-974. doi: 10.1016/0378-4274(95)03532-X

World Health Organization (2017). Nutritional Anaemias: Tools for Effective Prevention and contro. Geneva: WHO, 96. Available online at: https://www.who.int/publications/i/item/9789241513067 (accessed June 2, 2021).

World Health Organization (2021). Micronutrient Deficiencies, Iron Deficiency Anaemia. In: Nutrition: Nutrition topics. Geneva: WHO.

Xiong, H., Kakei, Y., Kobayashi, T., Guo, X., Nakazano, M., Takahashi, H., et al. (2013). Molecular evidence for phytosiderophore-induced improvement of iron nutrition of peanut intercropped with maize in calcareous soil. Plant Cell Environ. 36, 1888-1902. doi: 10.1111/pce.12097

Xue, P.-P., Carrillo, Y., Pino, V., Minasny, B., and Mc Bratney, A. B. (2018). Soil properties drive microbial community structure in a large scale transect in South Eastern Australia. Sci. Rep. 8:17725. doi: 10.1038/s41598-018-3 0005-8

Xue, Y., Xia, H., Christie, P., Zhang, Z., Li, L., and Tang, C. (2016). Crop acquisition of phosphorus, iron and zinc from soil in cereal/legume intercropping systems: a critical review. Ann. Bot. 117, 363-377. doi: 10.1093/aob/mcv182

Yadav, R., Ror, P., Rathore, P., Kumar, S., and Ramakrishna, W. (2020). Bacillus subtilis CP4, isolated from native soil in combination with arbuscular mycorrhizal fungi promotes biofortification, yield and metabolite production in wheat under field conditions. J. Appl. Microbiol. 131, 339-359. doi: 10.1111/ jam.14951

Yehuda, Z., Shenker, M., Hadar, Y., and Chen, Y. (2000). Remedy of chlorosis induced by iron deficiency in plants with the fungal siderophore rhizoferrin. J. Plant Nutr. 23, 1991-2006. doi: 10.1080/01904160009382160

Yuan, J., Chen, Y., Li, H., Lu, J., Zhao, H., Liu, M., et al. (2018). New insights into the cellular responses to iron nanoparticles in Capsicum annuum. Sci. Rep. 8:3228. doi: 10.1038/s41598-017-18055-w

Zaeem, M., Nadeem, M., Pham, T. H., Ashiq, W., Ali, W., Gilani, S. S. M., et al. (2019). The potential of corn-soybean intercropping to improve the soil health 
status and biomass production in cool climate boreal ecosystems. Sci Rep. 9:13148. doi: 10.1038/s41598-019-49558-3

Zamioudis, C., Hanson, J., and Pieterse, C. M. J. (2014). $\beta$-Glucosidase BGLU42 is a MYB72-dependent key regulator of rhizobacteria-induced systemic resistance and modulates iron deficiency responses in Arabidopsis roots. New Phytol. 204, 368-379. doi: 10.1111/nph.12980

Zanin, L., Tomasi, N., Cesco, S., Varanini, Z., and Pinton, R. (2019). Humic substances contribute to plant iron nutrition acting as chelators and biostimulants. Front. Plant Sci. 10:675. doi: 10.3389/fpls.2019.00675

Zhang, H., Sun, Y., Xie, X., Kim, M.-S., Dowd, S. E., and Paré, P. W. (2009). A soil bacterium regulates plant acquisition of iron via deficiency-inducible mechanisms. Plant J. 58, 568-577. doi: 10.1111/j.1365-313X.2009.03803.x

Zhang, L., Xing, J., and Lin, J. (2019). At the intersection of exocytosis and endocytosis in plants. New Phytol. 224, 1479-1489. doi: 10.1111/nph.16018

Zhang, Y., Xu, Y.-H., Yi, H.-Y., and Gong, J.-M. (2012). Vacuolar membrane transporters OsVIT1 and OsVIT2 modulate iron translocation between flag leaves and seeds in rice. Plant J. 72, 400-410. doi: 10.1111/j.1365-313X.2012. 05088.x

Zhou, C., Guo, J., Zhu, L., Xiao, X., Xie, Y., Zhu, J., et al. (2016). Paenibacillus polymyxa BFKC01 enhances plant iron absorption via improved root systems and activated iron acquisition mechanisms. Plant Physiol. Biochem. 105, 162173. doi: 10.1016/j.plaphy.2016.04.025

Zhou, C., Zhu, L., Ma, Z., and Wang, J. (2018). Improved iron acquisition of Astragalus sinicus under low iron-availability conditions by soil-borne bacteria Burkholderia cepacia. J. Plant. Interact. 13, 9-20. doi: 10.1080/17429145.2017. 1407000

Zhu, X. F., Wang, B., Song, W. F., Zheng, S. J., and Shen, R. F. (2016). Putrescine aleviates iron deficiency via NO-dependent reutilization of root cell-wall Fe in Arabidopsis. Plant Physiol. 170, 558-567. doi: 10.1104/pp.15.01617
Zielińska-Dawidziak, M. (2015). Plant ferritin-a source of iron to prevent its deficiency. Nutrients 7, 1184-1201. doi: 10.3390/nu7021184

Zribi, K., and Gharsalli, M. (2002). Effect of bicarbonate on growth and iron nutrition of pea. J. Plant Nutr. 25, 2143-2149. doi: 10.1081/PLN-120014066

Zuo, Y. M., Zhang, F. S., Li, X. L., and Cao, Y. P. (2000). Studies on the improvement in iron nutrition of peanut by intecropping maize on a calcareous soil. Plant Soil. 50, 1071-1078. doi: 10.1080/00380768.2004.10 408576

Zuo, Y., and Zhang, F. (2009). Iron and zinc biofortification strategies in dicot plants by intercropping with gramineous species. A review. Agron. Sustain. Dev. 29, 63-71. doi: 10.1051/agro:2008055

Conflict of Interest: The authors declare that the research was conducted in the absence of any commercial or financial relationships that could be construed as a potential conflict of interest.

Publisher's Note: All claims expressed in this article are solely those of the authors and do not necessarily represent those of their affiliated organizations, or those of the publisher, the editors and the reviewers. Any product that may be evaluated in this article, or claim that may be made by its manufacturer, is not guaranteed or endorsed by the publisher.

Copyright (c) 2021 Lurthy, Pivato, Lemanceau and Mazurier. This is an openaccess article distributed under the terms of the Creative Commons Attribution License (CC BY). The use, distribution or reproduction in other forums is permitted, provided the original author(s) and the copyright owner(s) are credited and that the original publication in this journal is cited, in accordance with accepted academic practice. No use, distribution or reproduction is permitted which does not comply with these terms. 